\title{
Discharge simulation in the sub-basins of the Amazon using ORCHIDEE forced by new datasets
}

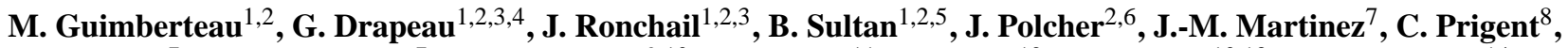 \\ J.-L. Guyot ${ }^{7}$, G. Cochonneau ${ }^{7}$, J. C. Espinoza ${ }^{9,10}$, N. Filizola ${ }^{11}$, P. Fraizy ${ }^{12}$, W. Lavado ${ }^{10,13}$, E. De Oliveira ${ }^{14}$, \\ R. Pombosa ${ }^{15}$, L. Noriega ${ }^{16}$, and P. Vauchel ${ }^{12}$ \\ ${ }^{1}$ Laboratoire d'Océanographie et du Climat: expérimentations et approches numériques (LOCEAN), UMR7159, Paris, France \\ ${ }^{2}$ Institut Pierre Simon Laplace (IPSL), Paris, France \\ ${ }^{3}$ Université Paris Diderot, Sorbonne Paris Cité, Paris, France \\ ${ }^{4}$ Pôle de Recherche pour l'Organisation et la Diffusion de l'Information Géographique (PRODIG), Paris, France \\ ${ }^{5}$ Institut de Recherche pour le Développement (IRD), Paris, France \\ ${ }^{6}$ Laboratoire de Météorologie Dynamique (LMD), CNRS, Paris, France \\ ${ }^{7}$ Institut de Recherche pour le Développement (IRD), Brasilia, Brazil \\ ${ }^{8}$ Laboratoire d'Etudes du Rayonnement et de la Matière en Astrophysique (LERMA), \\ Observatoire de Paris, CNRS, Paris, France \\ ${ }^{9}$ Instituto Geofisico del Perú, Lima, Perú \\ ${ }^{10}$ Universidad Agraria La Molina, Lima, Perú \\ ${ }^{11}$ Universidad Federal de Amazonas, Manaus, Brazil \\ ${ }^{12}$ Institut de Recherche pour le Développement (IRD), Lima, Perú \\ ${ }^{13}$ Servicio Nacional de meteorología e hidrología, Lima, Perú \\ ${ }^{14}$ Agência Nacional de Águas (ANA), Brasilia, Brazil \\ ${ }^{15}$ Instituto Nacional de meteorología e hidrología, Quito, Ecuador \\ ${ }^{16}$ Servicio Nacional de meteorología e hidrología, La Paz, Bolivia
}

Correspondence to: M. Guimberteau (matthieu.guimberteau@upmc.fr)

Received: 24 November 2011 - Published in Hydrol. Earth Syst. Sci. Discuss.: 15 December 2011

Revised: 1 March 2012 - Accepted: 15 March 2012 - Published: 22 March 2012

\begin{abstract}
The aim of this study is to evaluate the ability of the ORCHIDEE land surface model to simulate streamflows over each sub-basin of the Amazon River basin. For this purpose, simulations are performed with a routing module including the influence of floodplains and swamps on river discharge and validated against on-site hydrological measurements collected within the HYBAM observatory over the 1980-2000 period. When forced by the NCC global meteorological dataset, the initial version of ORCHIDEE shows discrepancies with ORE HYBAM measurements with underestimation by $15 \%$ of the annual mean streamflow at Óbidos hydrological station. Consequently, several improvements are incrementally added to the initial simulation in order to reduce those discrepancies. First, values of NCC precipitation are substituted by ORE HYBAM daily in-situ rainfall observations from the meteorological services of Amazonian countries, interpolated over the basin. It highly improves
\end{abstract}

the simulated streamflow over the northern and western parts of the basin, whereas streamflow over southern regions becomes overestimated, probably due to the extension of rainy spots that may be exaggerated by our interpolation method, or to an underestimation of simulated evapotranspiration when compared to flux tower measurements. Second, the initial map of maximal fractions of floodplains and swamps which largely underestimates floodplains areas over the main stem of the Amazon River and over the region of Llanos de Moxos in Bolivia, is substituted by a new one with a better agreement with different estimates over the basin. Simulated monthly water height is consequently better represented in ORCHIDEE when compared to Topex/Poseidon measurements over the main stem of the Amazon. Finally, a calibration of the time constant of the floodplain reservoir is performed to adjust the mean simulated seasonal peak flow at Óbidos in agreement with the observations. 


\section{Introduction}

The Amazon River basin, the largest basin in the world with an area of approximately 6.0 million $\mathrm{km}^{2}$, has the highest average discharge $\left(206000 \mathrm{~m}^{3} \mathrm{~s}^{-1}\right)$ (Callede et al., 2010) and it contributes to about $15-20 \%$ of the fresh water transported to the oceans (Richey et al., 1986). The present functioning of this basin is especially complex due to four elements: its extent over large ranges of latitude, longitude and altitude that organize its mean hydrological characteristics, the presence of extensive inundation zones that contribute to runoff control at annual and interannual time scales, the influence of the Atlantic and Pacific oceans that partly control the hydrological variability at different time scales, and the land use changes that are increasing since the seventies and lead to changes in the radiation and water balances. Yet, a good understanding of the present hydrological response of the Amazon River basin to various forcings is required to evaluate future changes. This can be partly achieved by using numerical models relying on hydroclimatological databases. So far, regional discharge simulation in the Amazon River basin has been conducted by different groups. Vörösmarty et al. (1989) and Costa and Foley (1997) initiated the simulation efforts in the Amazon River basin. Coe et al. (2002) simulated discharge in 121 stations of the Amazon River basin using an integrated biosphere simulator coupled to a hydrological routing algorithm and obtained good results for Brazilian basins. However, a discharge underestimation was found in the basins lying in other Amazonian countries, due to the lack of reliable rainfall information except for Brazil. Other deficiencies of the model, related to the river and floodplain morphology, have been corrected in Coe et al. (2007) and led to great improvement in the simulation of discharge, water height and flooded area. In Coe et al. (2009), the same authors used the model to characterize the role of deforestation on runoff evolution. Also using ISBA (Soil-Biosphere-Atmosphere Interaction) land surface model and the TRIP (Total Runoff integrating Pathways) river routing model, Decharme et al. (2008) compared their evaluations in the Parana, Orinoco and Amazon River basins with satellite-derived inundation estimates as well as in-situ river discharge observations. Recently an interesting modeling effort was introduced by Yamazaki et al. (2011), incorporating semi-explicit floodplain process. At the beginning of 21 st century, a distributed Large Basin Simulation Model, called MGB-IPH (an acronym from the Portuguese for Large Basins Model and Institute of Hydraulic Research), was developed by Collischonn and Tucci (2001). Applications of this model were initially developed for the La Plata basin (Allasia et al., 2006) and then for some Amazonian rivers, the Madeira (Ribeiro et al., 2005), the Tapajos, where satellitederived rainfall information is being used to run the model (Collischonn et al., 2008), and the Negro river, where spatial altimetry data is being used to complement the validation of the simulation (Getirana, 2010; Getirana et al., 2010).
The comparison of different rainfall products used to force MGB-IPH in the Negro basin shows that observed data give the most adequate discharge results (Getirana et al., 2011). Recently, developments towards a better representation of floodplains in the upper Parana River (Pantanal region) have been presented in Paz et al. (2010). Beighley et al. (2009) focused on the representation of water storage in the Amazon River basin and the factors accounting for its variability. Finally, Paiva et al. (2011) show that it is possible to employ full hydrodynamic models within large-scale hydrological models even using limited data for river geometry and floodplain characterization.

This present work aims to evaluate the simulation of discharge in the Amazon main stem and in its principal tributaries by the hydrological module SECHIBA (Schématisation des EChanges Hydriques à l'Interface Biosphère-Atmosphère, Ducoudré et al., 1993) of the land surface model (LSM) ORCHIDEE (ORganising Carbon and Hydrology In Dynamic EcosystEms) considering a 11-level hydrology (De Rosnay, 1999; De Rosnay et al., 2002; d'Orgeval, 2006; d'Orgeval et al., 2008), using a routing module (Polcher, 2003) and the representation of floodplains and swamps by d'Orgeval (2006). All these characteristics of the model are described in Sect. 2. The model is forced by NCC atmospheric data (NCEP/NCAR Corrected by CRU data, Ngo-Duc et al., 2005) detailed in Sect. 3.1. Ngo-Duc et al. (2005) previously compared observed and simulated discharge values by ORCHIDEE at the Óbidos station, on the main stem of the Amazon River. In that experiment, the authors found that the quality of simulations forced by this new 53-yr NCC data is better than the former ones forced by the GSWP2 (Global Soil Wetness Project 2, Dirmeyer et al., 2002; Zhao and Dirmeyer, 2003) forcing dataset. However, the discharge simulations forced by NCC identified some discrepancies in the annual cycles in some tributaries of the Amazon River basin and over- or underestimations of the mean discharge in the southern and western tributaries, respectively (J. Ronchail et al., personal communication, 2005). Improvements to former simulations may be expected thanks to the recent availability of a comprehensive observed precipitation dataset for the Amazon River basin made available within the framework of the ORE (Environmental Research Observatory) HYBAM (Geodynamical, hydrological and biogeochemical control of erosion/alteration and material transport in the Amazon River basin, Cochonneau et al., 2006) and of new satellite-derived maps of floodplains and swamps distribution (Martinez and Le Toan, 2007; Prigent et al., 2007). These new data datasets are described in Sect. 3.3. Our aim is to verify whether ORCHIDEE, forced by these new datasets, properly reproduces the different specificities of the main stem and of some large subbasins of the Amazon when compared with observations (described in Sect. 3.2). Therefore, the new datasets are incrementally added to the initial simulation (ORCH1) performed with NCC and initial maps of flooded areas distribution. 
First, in simulation ORCH2, we test in Sect. 4 the impact of ORE HYBAM precipitation on simulated water budget (Sect. 4.1) and simulated streamflow (Sect. 4.2) over the basin. The different characteristics of the simulated discharges (accuracy of the mean annual value, precision of the seasonal cycle and representation of the interannual variability) are studied in the different locations of the basin. Finally, the impact of the new spatial distribution of flooded areas on the time position of flooding and the water height of the floodplains is investigated through simulation ORCH3 in Sect. 5. Those improvements allowed us to calibrate the streamflow at Óbidos (simulation ORCH4). This calibration can be crucial to use ORCHIDEE as a tool to predict future changes in Amazon River basin hydrology. Indeed, an increase of extremes (floods and droughts) has already been observed since the nineties (Espinoza et al., 2009a). It may be part of the long-term variability described by Callede et al. (2004) and Marengo (2004) but may be also a consequence of the climatic change described for South America by the IPCC (Solomon et al., 2007).

\section{The land surface model ORCHIDEE}

\subsection{Hydrological module and vegetation}

SECHIBA is the hydrological module of ORCHIDEE that simulates the fluxes between the soil and the atmosphere through the vegetation, and computes runoff and drainage, which are both discharged to the ocean. The hydrological module used in this study is based on developments by De Rosnay et al. (2000, 2002) and d'Orgeval (2006). Physical processes of vertical soil flow are represented by a diffusion-type equation resolved on a fine vertical discretization (11 levels) and the partitioning between surface infiltration and runoff is represented in the model. The hydrological module is fully described by De Rosnay (1999); De Rosnay et al. (2002); d'Orgeval (2006); d'Orgeval et al. (2008).

In order to reduce noise in our simulation of streamflow, no complex scenario such as deforestation, land use or forest fire is taken into account in this study. Vegetation distribution and LAI seasonality are prescribed in the model through global maps. In each grid-cell, up to thirteen Plant Functional Types (PFTs) can be represented simultaneously according to the International Geosphere Biosphere Programme (IGBP, Belward et al., 1999) and the Olson classification (Olson et al., 1983). Values of LAI come from the Normalized Difference Vegetation Index (NDVI) observations (Belward et al., 1999). The PFTs are grouped into 3 ensembles (bare soil, trees and grass/crops) and a water balance is computed for each one given a dominant soil type over the grid box defined by a map derived from Reynolds et al. (1999)'s dataset.

\subsection{Routing module}

The routing scheme (Polcher, 2003), described in Ngo-Duc et al. (2007), is activated in the model in order to carry the water from runoff and drainage simulated by SECHIBA to the ocean through reservoirs, with some delay. The routing scheme is based on a parametrization of the water flow on a global scale (Miller et al., 1994; Hagemann and Dumenil, 1998). Given the global map of the main watersheds (Oki et al., 1999; Fekete et al., 1999; Vörösmarty et al., 2000) which delineates the boundaries of sub-basins and gives the eight possible directions of water flow within the pixel, the surface runoff and the deep drainage are routed to the ocean. The resolution of the basin map is $0.5^{\circ}$, higher than usual resolution used when LSMs are applied. Therefore, we can have more than one basin in SECHIBA grid cell (sub-basins) and the water can flow either to the next sub-basin within the same grid cell or to the neighboring cell. In each sub-basin, the water is routed through a cascade of three linear reservoirs which do not interact with the atmosphere. The water balance within each reservoir is computed using the following continuity equation:

$\frac{\mathrm{d} V_{i}}{\mathrm{~d} t}=Q_{i}^{\text {in }}-Q_{i}^{\text {out }}$

where $V_{i}(\mathrm{~kg})$ is the water amount in the reservoir $i$ considered ( $i=1,2$ or 3 ), $Q_{i}^{\text {in }}$ and $Q_{i}^{\text {out }}$ (both in $\mathrm{kg} \mathrm{day}^{-1}$ ) are, respectively the total inflow and outflow of the reservoir $i$.

The slow and deep reservoir $(i=3)$ collects the deep drainage $D$ (water moving downward from surface water to groundwater) computed by the land surface scheme, whereas the fast reservoir $(i=2)$ collects the computed surface runoff $R$ (portion of incoming water such as precipitation and irrigation not infiltrating in the soil but discharged from the area). Both discharge flows into a third reservoir, called stream reservoir $(i=1)$, of the next sub-basin downstream. According to Eq. (1), the continuity equations can be written for each of the three reservoirs as below:

$$
\begin{aligned}
\frac{\mathrm{d} V_{1}}{\mathrm{~d} t} & =\sum_{x} Q_{x}^{\text {in }}-Q_{1}^{\text {out }} \\
\frac{\mathrm{d} V_{2}}{\mathrm{~d} t} & =R-Q_{2}^{\text {out }} \\
\frac{\mathrm{d} V_{3}}{\mathrm{~d} t} & =D-Q_{3}^{\text {out }}
\end{aligned}
$$

where $Q_{x}^{\text {in }}\left(\mathrm{kg} \mathrm{day}^{-1}\right)$ is the total inflow coming from the neighboring cells or sub-basins $x$ and $R$ and $D$ (both in $\mathrm{kg} \mathrm{day}^{-1}$ ) are, respectively surface runoff and deep drainage.

The flow chart in Fig. 1 represents the routing channel modeling in SECHIBA through an example of two subbasins (A and B) included in a same grid cell p. Three reservoirs are allocated to each sub-basin. At each routing time step $\Delta t=1$ day, the routing scheme computes water flows as follows: the sum of the surface runoff and the 


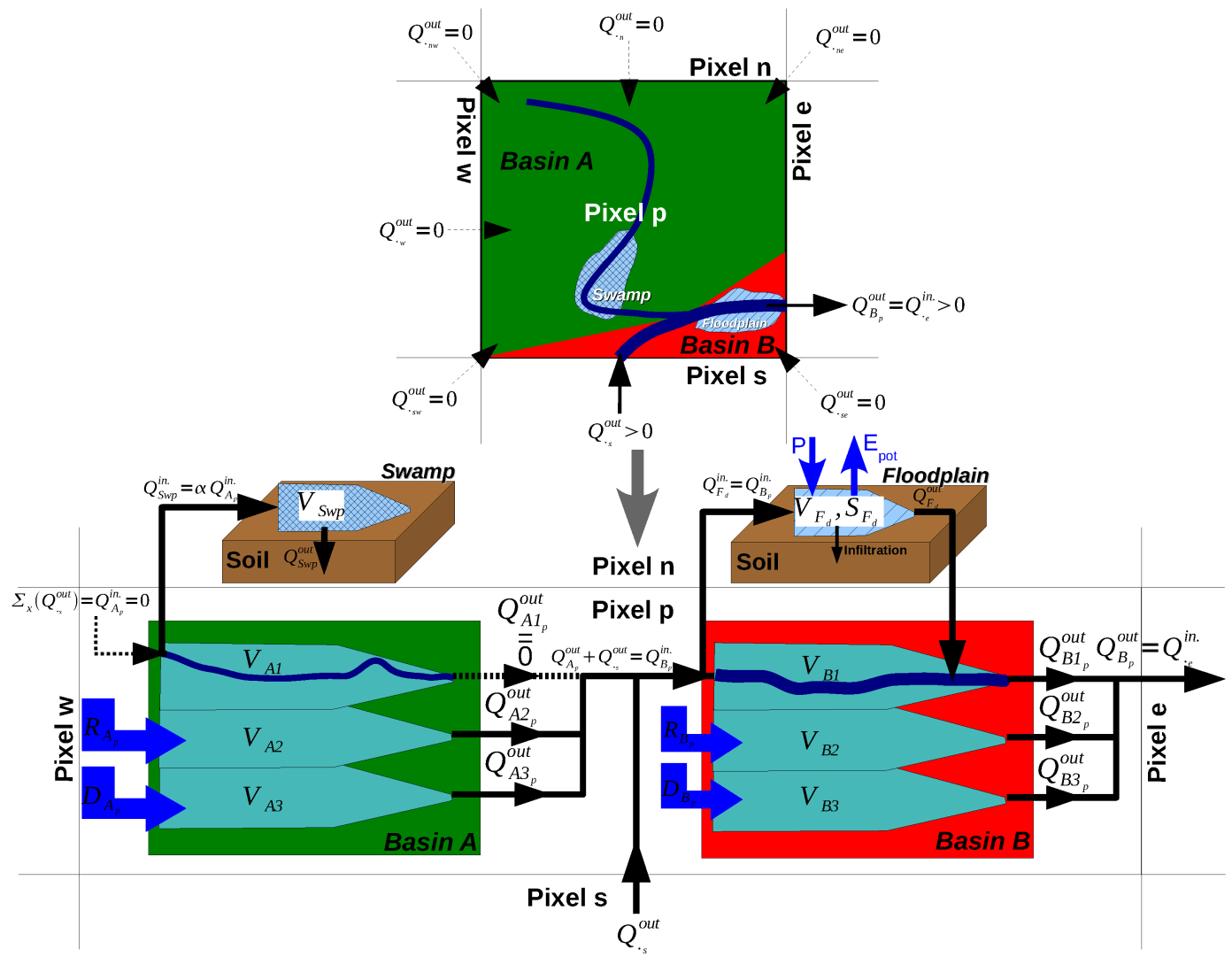

Fig. 1. Flow chart of the routing channel connected with floodplains/swamps module in ORCHIDEE. Example of two sub-basins A (with a swamp fraction) and B (with a floodplain fraction) included into one grid cell $\mathrm{p}$.

deep drainage is spread in the grid cell $\mathrm{p}$ over the two subbasins, proportionally to their surface. The surface runoff of the sub-basins A and $\mathrm{B}$ (respectively $R_{\mathrm{A}_{\mathrm{p}}}$ and $R_{\mathrm{B}_{\mathrm{p}}}$ ) flows into their respective fast reservoirs of volume $V_{\mathrm{A} 2}$ and $V_{\mathrm{B} 2}$. The deep drainage $D_{\mathrm{A}_{\mathrm{p}}}$ and $D_{\mathrm{B}_{\mathrm{p}}}$ flows into the slow reservoirs of volume $V_{\mathrm{A} 3}$ and $V_{\mathrm{B} 3}$. The water amount of the river is represented by the stream reservoir. The stream reservoir of the sub-basin $\mathrm{A}$ is assumed to be empty in this example $\left(V_{\mathrm{A} 1}=0\right)$, the outflows from the neighboring pixels $x$ $(x=\mathrm{sw}, \mathrm{w}, \mathrm{nw}, \mathrm{n}, \mathrm{ne})$ to sub-basin A being null $\left(\sum_{x} Q_{x}^{\text {out }}=0\right)$. The stream reservoir of the downstream sub-basin B of volume $V_{\mathrm{B} 1}$ collects the sum of the outflows $Q_{\mathrm{A}_{\mathrm{p}}}^{\text {out }}$ from the three reservoirs of the sub-basin A (see Eq. 5) and the outflow $Q_{\mathrm{s}}^{\text {out }}$ coming from the pixel s (Eq. 6).

$Q_{\mathrm{A}_{\mathrm{p}}}^{\text {out }}=\sum_{i=1}^{3} Q_{\mathrm{A} i_{\mathrm{p}}}^{\text {out }}$

where $Q_{\mathrm{A}_{\mathrm{p}}}^{\text {out }}\left(\mathrm{kg} \mathrm{day}^{-1}\right)$ is the total outflow from the subbasin A in the pixel $\mathrm{p}$ and $Q_{\mathrm{A} i_{\mathrm{p}}}^{\text {out }}\left(\mathrm{kg} \mathrm{day}^{-1}\right)$ the outflow from each reservoir $i$ of the sub-basin A in the pixel $\mathrm{p}$.

$Q_{\mathrm{B}_{\mathrm{p}}}^{\text {in }}=Q_{\mathrm{A}_{\mathrm{p}}}^{\text {out }}+Q_{\mathrm{s}}^{\text {out }}$ where $Q_{\mathrm{B}_{\mathrm{p}}}^{\mathrm{in}}\left(\mathrm{kg} \mathrm{day}^{-1}\right)$ is the total inflow of the sub-basin B in the pixel $\mathrm{p}$ and $Q_{\mathrm{s}}^{\text {out }}\left(\mathrm{kg} \mathrm{day}^{-1}\right)$ the total outflow from the pixel s.

The sum of the outflows from the reservoirs of the subbasin B in the pixel p goes to the pixel e. Runoff and drainage are routed through this cascade of reservoirs. In our model, the volume of water $V_{i}$ into the reservoir $i$ is assumed to be linearly related to its outflow $Q_{i}^{\text {out: }}$

$V_{i}=\left(g_{i} \cdot k\right) \cdot Q_{i}^{\text {out }}$

where $g_{i}\left(\right.$ day $\left.\mathrm{m}^{-1}\right)$ is a property of the reservoir $i$ and $k(\mathrm{~m})$ a water retention index.

The water travel simulated by the routing scheme is dependent on a water retention index $k$, given by a $0.5^{\circ}$ resolution map for each pixel performed from a simplification of Manning's formula (Dingman, 1994; Ducharne et al., 2003):

$k=\sqrt{\frac{d^{3}}{\Delta z}}$

where $d(\mathrm{~m})$ is the river length from one subgrid basin to the next subgrid, and $\Delta z(\mathrm{~m})$ the height lost over the path of the river. 
The value of $g$ in the Eq. (7) has been calibrated for the three reservoirs over the Senegal river basin only, during the $1^{\circ}$ NCC resolution simulations (Ngo-Duc et al., 2005; NgoDuc, 2006) and generalized for all the basins of the world. The "slow reservoir" and the "fast reservoir" have the highest value ( $g_{2}=g_{3}=3.0$ days $\mathrm{m}^{-1}$, d'Orgeval, 2006) in order to simulate the groundwater. The "stream reservoir", which represents all the water of the stream, has the lowest value $\left(g_{1}=0.24\right.$ day $\left.^{-1}\right)$. Those figures are the same for all the basins of the world. The resulting product $g_{i} \cdot k$ represents the time constant $T_{i}$ (day) which is an e-folding time, the time necessary for the water amount in the stream reservoir to decrease by a factor $e$. Hence, it gives an order of magnitude of the travel time through this reservoir between the sub-basin considered and its downstream neighbor.

\subsection{Floodplains and swamps module}

Floodplains are land areas adjacent to streams that are subject to recurring inundation. The stream overflows its banks onto adjacent lands. Over the Amazon River basin, Richey et al. (1989) estimated that up to $30 \%$ of the water in the main stem is derived from water that passed through the floodplain. Thus, as the floodplain storage is significant in relation to the streamflow, it must be taken into account explicitly. Moreover, water can be stored in swamps, it saturates and infiltrates into the soil and does not return to the river. These inundated areas mainly correspond to flooded forest areas in the Amazon River basin. Thus, the module of floodplains/swamps developed in ORCHIDEE by d'Orgeval (2006) is used for this study in order to better represent the timing of flow in some regions of the Amazon River basin strongly affected by flooding. The parametrization is described in detail by d'Orgeval (2006) and d'Orgeval et al. (2008). A map of maximal fractions of floodplains (MFF) and swamps (MFS) derived from the Global Lakes and Wetlands Database (GLWD, Lehner and Döll, 2004) is initially prescribed to the model. Floodplains and swamps in the model derive, respectively from three types of water surfaces (Reservoir, Freshwater marsh-Floodplain and Pan-Brackish/Saline wetland) and one type (Swamp forestFlooded forest) according to GLWD database.

Over floodplains areas, the streamflow $Q_{\mathrm{B}_{\mathrm{p}}}^{\text {in }}$ from head waters of the reservoirs of the basin A flows into a reservoir of floodplains $\left(Q_{\mathrm{B}_{\mathrm{p}}}^{\text {in }}=Q_{F_{\mathrm{d}}}^{\text {in }}\right)$ instead of the stream reservoir of volume $V_{\mathrm{B} 1}$ of the next downstream (Fig. 1). The surface $S_{\mathrm{Fd}}$ of the floodplain depends on the shape of the bottom of the floodplain in order to simulate the timing between the rise of water level and its expansion. Finally, water from the floodplains reservoir that has not evaporated or reinfiltrated the soil flows into the stream reservoir of volume $V_{\mathrm{B} 1}$ of the basin $\mathrm{B}$ after a delay. This delay is characterized by the time constant $T_{\mathrm{Fd}}$ (day) function of the surface of the floodplains $S_{\mathrm{Fd}}$ :
Table 1. List of atmospheric forcing variables in NCC.

\begin{tabular}{|c|c|c|}
\hline Name & Description & Units \\
\hline$T_{\text {air }}$ & Two-meter air temperature & $\mathrm{K}$ \\
\hline$Q_{\text {air }}$ & Two-meter air specific humidity & $\mathrm{kg} \mathrm{kg}^{-1}$ \\
\hline Wind_N & Ten-meter wind speed ( $u$ component) & $\mathrm{m} \mathrm{s}^{-1}$ \\
\hline Wind_E & Ten-meter wind speed ( $v$ component) & $\mathrm{ms}^{-1}$ \\
\hline$P_{\text {surf }}$ & Surface pressure & $\mathrm{Pa}$ \\
\hline $\mathrm{SW}_{\text {down }}$ & Surface downward short wave flux & $\mathrm{W} \mathrm{m}^{-2}$ \\
\hline $\mathrm{LW}_{\text {down }}$ & Surface downward long wave flux & $\mathrm{W} \mathrm{m}^{-2}$ \\
\hline Rainf & Rainfall rate & $\mathrm{kg} \mathrm{m}^{-2} \mathrm{~s}^{-1}$ \\
\hline Snowf & Snowfall rate & $\mathrm{kg} \mathrm{m}^{-2} \mathrm{~s}^{-1}$ \\
\hline
\end{tabular}

$T_{\mathrm{Fd}}=\left(g_{\mathrm{Fd}} \cdot k\right) \cdot \frac{S_{\mathrm{Fd}}}{S_{\mathrm{B}}}$

where $g_{\mathrm{Fd}}=4.0$ days $\mathrm{m}^{-1}$ is a property of the floodplain reservoir, $S_{\mathrm{Fd}}\left(\mathrm{m}^{2}\right)$ the surface of the floodplain and $S_{\mathrm{B}}\left(\mathrm{m}^{2}\right)$ the surface of the basin.

The value of $g_{\mathrm{Fd}}$ has been calibrated through observations in the Niger Inner Delta and can thus be different for the Amazon River basin as it will be shown in Sect. 5.1.

Over swamp areas, a fraction of water $\alpha=0.2$ is uptaken from the stream reservoir of volume $V_{\mathrm{A} 1}\left(Q_{\mathrm{Swp}}^{\text {in }}=\alpha Q_{\mathrm{A}_{\mathrm{p}}}^{\text {in }}\right)$. It is transferred into soil moisture (Fig. 1) and thus does not return directly to the river. The swamp storage enhances transpiration of forest where the soil is saturated, reducing bare soil evaporation.

\section{Datasets}

In this section, the datasets used in this work are presented: the atmospheric forcing, the validation data and the new rainfall and flooded areas distribution datasets used to force ORCHIDEE.

\subsection{Atmospheric forcing}

The atmospheric data set used as input to ORCHIDEE is NCC (NCEP/NCAR Corrected by CRU data, Ngo-Duc et al., 2005) based on the NCEP/NCAR reanalysis project (Kistler et al., 2001) and in-situ observations. The spatial resolution is $1^{\circ} \times 1^{\circ}$ for the whole globe. The temporal resolution is six hours and the time series cover the 1948-2000 period. All variables present in the forcing are summarized in Table 1 . The NCC precipitation is a hybridization of NCEP and CRU precipitation (New et al., 2000); the radiation is a hybridization of NCEP and SRB radiation (Surface Radiation Budget data produced at NASA Langley Research Center) used for a bias correction of the reanalysis product. The data have allowed 50-yr river flows to be simulated over the planet (Ngo-Duc et al., 2005). 
Table 2. List of ORE HYBAM gauge stations over the Amazon River basin. Except for the streamflow at the river mouth (1972-2003), the mean annual discharge $\left(Q_{\text {mean }}\right)$ corresponds to the mean annual value of ORE HYBAM data for the mean time period 1980-2000.

\begin{tabular}{lllrrrr}
\hline Station & Abbreviation & River & Latitude & Longitude & $Q_{\text {mean }}\left(\mathrm{m}^{3} \mathrm{~s}^{-1}\right)$ & Area $^{\left(\mathrm{km}^{2}\right)}$ \\
& & & & & & \\
\hline Mouth (Callede et al., 2010) & AMAZ & Amazonas & $\sim 0.00$ & $\sim-50.5$ & 206000 & 5961000 \\
Óbidos & OBI & Amazonas & -1.95 & -55.30 & 169515 & 4680000 \\
Manacapuru & MANA & Solimoes & -3.31 & -60.61 & 100819 & 2242400 \\
Sao Paulo de Olivença & SPO & Solimoes & -3.45 & -68.75 & 46206 & 990781 \\
Tamshiyacu & TAM & Solimoes & -4.00 & -73.16 & 30530 & 726400 \\
Fazenda Vista Alegre & FVA & Madeira & -4.68 & -60.03 & 28374 & 1293600 \\
Porto Velho & PVE & Madeira & -8.74 & -63.92 & 19418 & 954400 \\
Guajara-Mirim & GMIR & Mamore & -10.99 & -65.55 & 8041 & 532800 \\
Rurrenabaque & RUR & Beni & -14.55 & -67.55 & 1986 & 67500 \\
Labrea & LAB & Purus & -7.25 & -64.80 & 5472 & 230000 \\
Gaviao & GAV & Jurua & -4.84 & -66.85 & 4632 & 170400 \\
Acanaui & ACA & Japura & -1.82 & -66.60 & 14075 & 251800 \\
Serrinha & SER & Negro & -0.48 & -64.83 & 16193 & 291100 \\
Caracarai & CARA & Branco & +1.83 & -61.08 & 2780 & 130600 \\
Sao Francisco & SFR & Jari & -0.41 & -52.33 & 990 & 51343 \\
Altamira & ALT & Xingu & -3.38 & -52.14 & 8000 & 469100 \\
Itaituba & ITA & Tapajos & -4.24 & -56.00 & 11789 & 461100 \\
\hline
\end{tabular}

\subsection{Data of validation}

\subsubsection{ORE HYBAM gauge stations}

Discharge data has been gathered and complemented within the frame of the ORE (Environmental Research Observatory) HYBAM (Geodynamical, hydrological and biogeochemical control of erosion/alteration and material transport in the Amazon River basin - http://www.ore-hybam.org/), a partnership which associates the meteorological and hydrological services of the Amazonian countries (Agéncia Nacional de Águas Water National Office/ANA in Brazil (http: //www2.ana.gov.br/), Servicio Nacional de Meteorología e Hidrología/National Meteorology and Hydrology Service/SENAMHI in Peru (http://www.senamhi.gob.pe/) and Bolivia (http://www.senamhi.gob.bo/), Instituto Nacional de Meteorología e Hidrología / National Meteorology and Hydrology Institute/INAMHI in Ecuador (http://www.inamhi. gov.ec/)) and the French Institute of Research for Development (IRD - http://www.ird.fr/). The rating curves have been determined using the stream gauging measurements, recently with Acoustic Doppler Current Profiler (ADCP), and have been used to convert the water level series into discharge data. The daily water level data were corrected when necessary, with missing values estimated by correlation with data from upstream or downstream stations. Sixteen stations out of eighty were chosen to realize the comparison with simulated data (Fig. 2 and Table 2). The choice of these stations depended on:

- The length of the records. Those beginning in the late seventies were preferred to the others in order to get

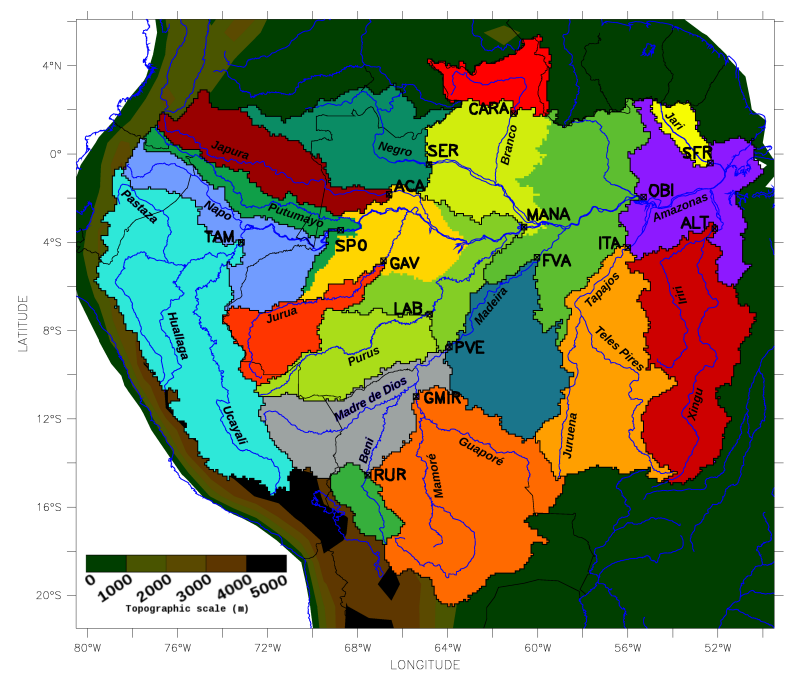

Fig. 2. Map of the Amazon River sub-basins and the main rivers. Localization of the main ORE HYBAM gauge stations (see Table 2 for their coordinates). Color is used to distinguish the different subbasins. Topographic scale is indicated.

longer common series with the simulated data. However, in order to have information about most subbasins, some short series were retained in places where no other record exists.

- The proximity of the stations. A choice was made between stations close to each other based on the reliability of their records (absence of missing values). 
- The size of the river. Some very small rivers were not recognizable with ORCHIDEE due to the coarse resolution.

\subsubsection{Topex/Poseidon measurements}

Surface monitoring by satellite altimetry has been performed on the whole Earth since 1993 (Crétaux et al., 2011). Altimetry datasets are available over the main stem of the Amazon and the Rio Negro-Branco rivers for a time period common to ours (1993-2000) thanks to Topex/Poseidon satellite mission. These measurements are used to assess the accuracy of ORCHIDEE to simulate floodplain height variability.

\subsection{New basis of observations over the Amazon River basin}

In order to simulate the streamflow with higher accuracy over the Amazon River basin, a new set of observations of precipitation is used to force ORCHIDEE and validate NCC. A new map of MFF and MFS based on observations is also tested and compared with the initial map prescribed to the model. The details of the construction and implementation of these new datasets are described in this section.

\subsubsection{ORE HYBAM precipitation}

Global rainfall datasets usually rely on very sparse in-situ observations over the Amazon River basin. Consequently, the Amazonian precipitation is often poorly represented in such datasets, especially regarding the plain of the Andean countries (Espinoza et al., 2009b). Within the frame of the ORE HYBAM, daily rainfall data from 1488 rain gauges have been gathered, from 1975 to 2009 . A quality control based on the application of the Regional Vector Method (RVM) on the rainfall values (Espinoza et al., 2009b) was then performed over the Amazon River basin. RVM enables to discriminate stations with lowest probability of errors in their series. Finally, 752 rain gauges approved by RVM were retained, with data covering more than five-year continuous periods. The density of ORE HYBAM stations is about $125\left[/ 10^{6} \mathrm{~km}^{2}\right]$ over the Amazon basin. This density is compared to the minimum rain gauge density requirements to prevent the effect of poor forcing precipitation on runoff simulation. ORE HYBAM density is higher than Oki et al. (1999)'s (30 $\left.\left[/ 10^{6} \mathrm{~km}^{2}\right]\right)$ and Rudolf et al. (1994)'s $\left(80\left[/ 10^{6} \mathrm{~km}^{2}\right]\right)$ recommendations. Moreover, it is close to WMO (World Meteorological Organization) recommendation (100 to $400\left[/ 10^{6} \mathrm{~km}^{2}\right]$, WMO, 1994) for operational purposes. Because a few extremely rainy spots located on the foothills of the Eastern Andes bring large amounts of water to the western and south-western parts of the basin (Killeen et al., 2007), we then chose to replace missing values of these particular stations by estimated values using linear regressions or by long-term climatological means. A strong underestimation of the rainfall input is thus avoided for the periods when records of one or several of these wet spots are missing. The concerned locations are the Chapare region in Bolivia (Cristal Mayu and Misicuni stations), the ManuTambopata area (Quincemil and San Gaban stations) and the Selva Central region (Tingo Maria station) in Peru. In-situ observations were afterward spatially interpolated to the resolution of $\mathrm{NCC}\left(1^{\circ} \times 1^{\circ}\right)$. Geostatistics have been widely used to interpolate environmental variables such as rainfall (Goovaerts, 2000; Hevesi et al., 1992). Ordinary kriging has notably been shown to provide better estimates than conventional methods, as it takes into account the spatial dependence between neighbouring observations, which is expressed by a semi-variogram. In this study, ordinary kriging was thus performed to generate an observation-based gridded daily rainfall dataset. Finally, because other NCC variables were available at a 6-h temporal resolution, daily rainfall grids were segmented at this resolution following a diurnal cycle as described in NCC precipitation data. If the NCC precipitation is null for the four $6 \mathrm{~h}$ time-steps in the day, the ORE HYBAM daily value is spread equally over the time-steps.

Mean annual value of NCC precipitation over the basin is about $2044 \mathrm{~mm} \mathrm{yr}^{-1}$ whereas ORE HYBAM precipitation shows a higher value than NCC $\left(2190 \mathrm{~mm} \mathrm{yr}^{-1}\right.$ i.e. $\left.+7.1 \%\right)$. The mean annual spatial distribution in precipitation is shown over the Amazon River basin for both datasets in Fig. 3a,b and their difference is calculated (Fig. 3c). In both datasets, the spatial distribution of precipitation of the Amazon River basin is quite similar. The rainiest regions (3000 $\mathrm{mm} \mathrm{yr}^{-1}$ and more) are located in the northwest of the basin (Colombia, North of the Ecuadorian Amazon, Northeast of Peru and Northwest of Brazil). Rainfall is also abundant close to the average position of the South Atlantic Convergence Zone (SACZ), established during austral summer from the Northwest of the Amazon to the Subtropical South Atlantic (Vera et al., 2006). Rainfall decreases toward the tropics, reaching less than $1500 \mathrm{~mm} \mathrm{yr}^{-1}$ in the PeruvianBolivian plain and toward the north in the Roraima Brazilian state. Rainfall also diminishes with altitude: in the Andes, over $2000 \mathrm{~m}$, annual rainfalls lower than $1000 \mathrm{~mm}$ are the most frequent. However, some differences in precipitation rate exist between the two datasets. ORE HYBAM depicts a sharp increase by 250 to $750 \mathrm{~mm} \mathrm{yr}^{-1}$ of the amount of rainfall in the north-west of the basin toward the southern and eastern part of this area. Extremely high values can be measured in the wet spots of the Eastern Andes foothills, in positions that favor strong air uplift; in these very rainy spots scattered along the Cordillera, annual rainfall reaches 5000 to $6000 \mathrm{~mm}$ with ORE HYBAM (regions of Churuyacu in Colombia, of the Reventador Volcano in Ecuador, of San Gabán and Tingo Maria in Peru, of the Chaparé in Bolivia) whereas these spots of precipitation are much less significant in NCC dataset. Finally, drier regions are present in ORE HYBAM compared to NCC over the south-east of the basin, the region of the Amazon mouth, the extreme north of the basin and over Ecuador and Central Peru. 


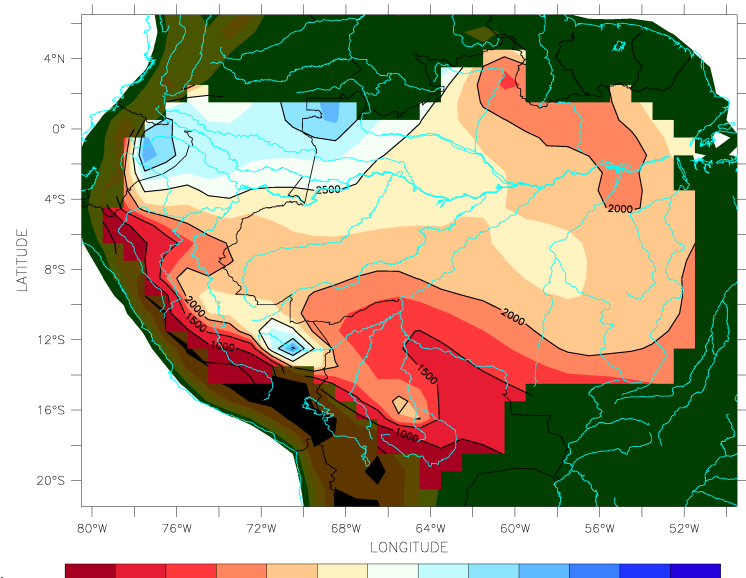

(a)

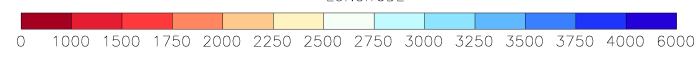

(b)
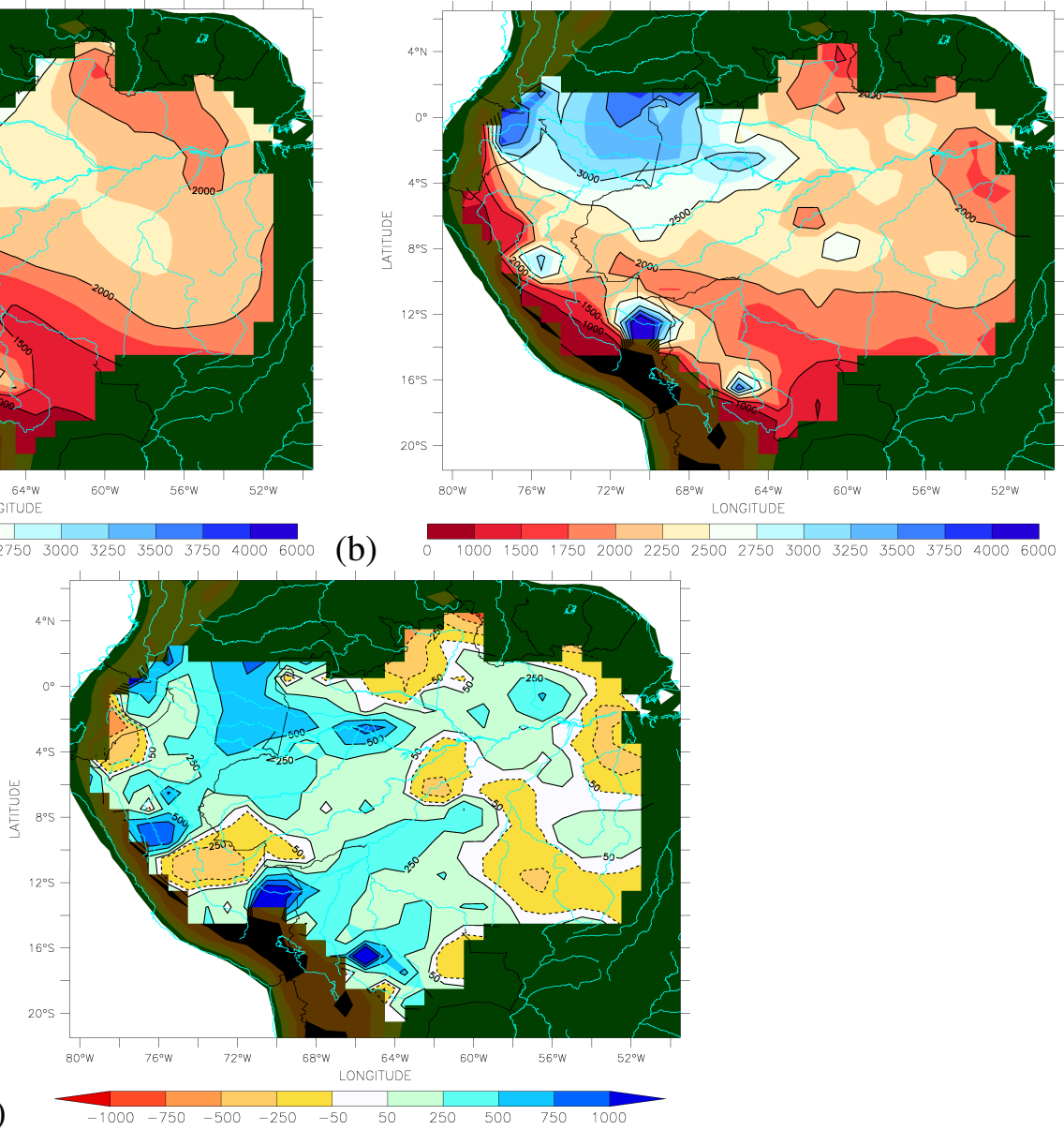

Fig. 3. Precipitation ( $\mathrm{mm} \mathrm{yr}^{-1}$ ) over the Amazon River basin from (a) NCC and (b) ORE HYBAM. (c) Differences between (b) and (a). For topographic scale, see Fig. 2.

\subsubsection{Map of maximal fractions of floodplains and swamps}

Initially, the maps of MFF and MFS prescribed to ORCHIDEE were derived from the GLWD dataset of Lehner and Döll (2004) (hereafter called "GLWD"). In this study, a new map (hereafter called "PRIMA") is produced where MFF and MFS are, respectively derived from Prigent et al. (2007) and Martinez and Le Toan (2007) dataset at $0.25^{\circ} \times 0.25^{\circ}$ and interpolated at $0.5^{\circ} \times 0.5^{\circ}$ for ORCHIDEE. Prigent et al. (2007) estimated monthly inundated fractions over the world by multisatellite method for eight years (1993-2000). Then, for each $0.5^{\circ}$ pixel of the Amazon River basin, as we need it for ORCHIDEE, we determine the maximum value that has been recorded during the $8 \mathrm{yr}$ observation. As there is no distinction between floodplains and swamps in Prigent et al. (2007)'s estimates, we apply to the maximum value a ratio of their maximal distribution using the 1995-1996 flood estimate by Martinez and Le Toan (2007) who distinguish floodplains and flooded forests areas.
The GLWD and PRIMA maps are compared for floodplains (Fig. 4) and swamps (Fig. 5). For both water surfaces, the difference between the two maps is performed. For both datasets, floodplains are located along the main stem of the Solimoes-Amazon River, in the southern region of the basin in Llanos de Moxos and to a lesser extent along the Ireng river (in GLWD) or the Branco river (in PRIMA) in the northernmost region of the basin (Fig. 4). However, MFF of PRIMA map are globally higher than GLWD (respectively about 4.2 and $2.6 \%$ of the total area of the Amazon River basin according to Table 3). Moreover, in PRIMA map, many MFF lower than $5 \%$ within the mesh cover almost all the basin whereas GLWD does not give data over these regions. The difference in MFF between the two maps is particularly high along the main stem of the Solimoes-Amazon River and especially near the mouth (between +5 to $+15 \%$ before Manacapuru to more than $+70 \%$ around Óbidos, see Fig. 2 and Table 2 for localization of the two stations). We note that a small percentage of this difference (up to about $2 \%$ around Óbidos) is explained by the fact that Prigent et al. 

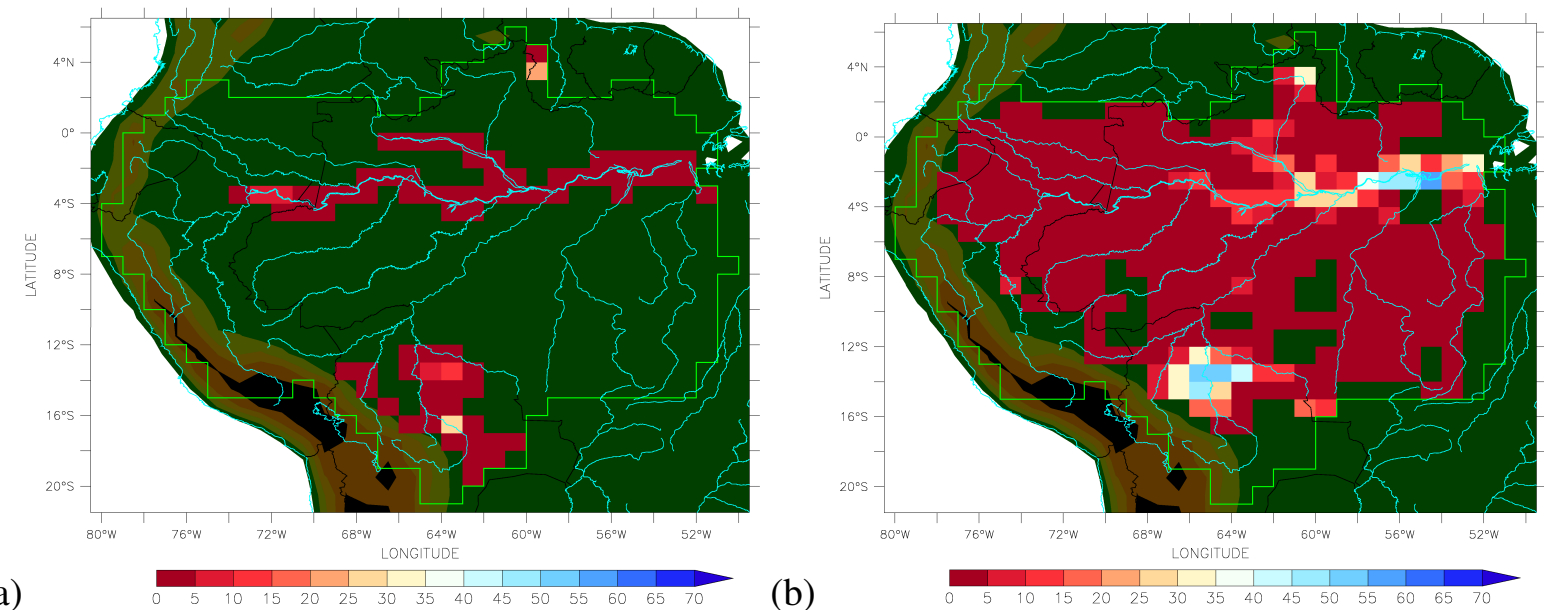

(a)

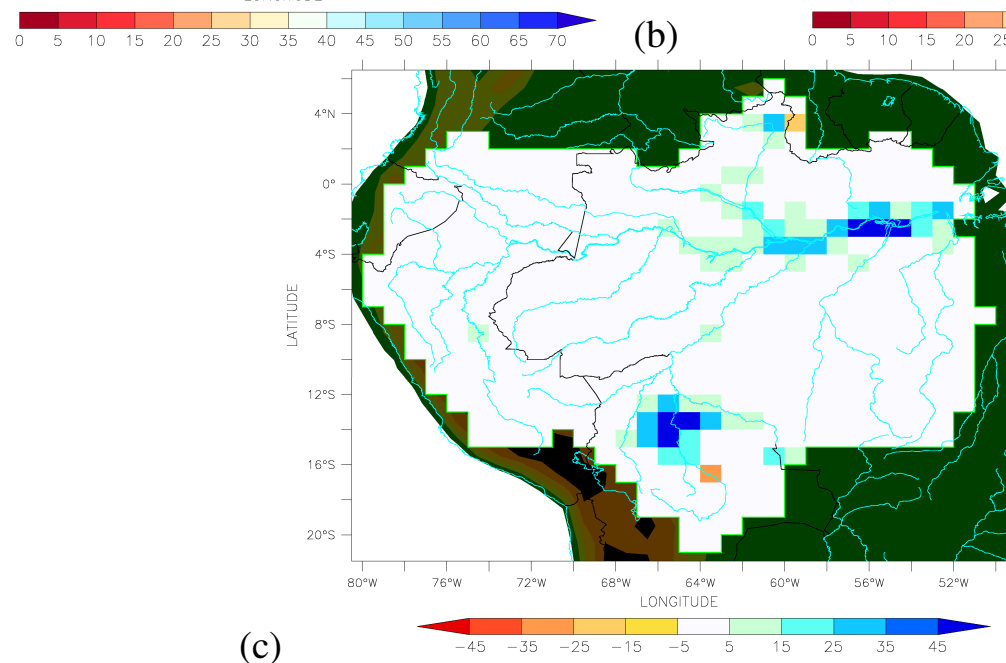

Fig. 4. Maximal fraction of floodplains within the mesh (\% of the mesh area) over the Amazon River basin from (a) GLWD and (b) PRIMA. (c) Differences between (b) and (a). Dark green and brown colors indicate the topography of the region. For topographic scale, see Fig. 2.

(2007)'s data take into account the surface of the river while Lehner and Döll (2004) data does not. In the south, the region of Llanos de Moxos shows the same order of increase in MFF with PRIMA dataset particularly over the Mamoré river in Bolivia. In Llanos de Moxos and along the main stem of the Solimoes-Amazon River, PRIMA is in better agreement with Hamilton et al. (2002)'s estimates with an underestimation of MFF by $30 \%$ which is much lower than GLWD (near $100 \%$ ) according to Table 4. In the North, at Roraima region, PRIMA is again in better agreement with Hamilton et al. (2002)'s estimates (about $+15 \%$ ) than GLWD (about $-70 \%$ ). For MFS, PRIMA presents half the extent of GLWD across the river basin (Table 3). According to Fig. 5c, this decrease is observed over the western part of the basin and mainly in the Northern Peruvian region (up to $45 \%$ more over some pixels), the south-easternmost part of the basin and along the main stem near the mouth of the Amazon River. On the other hand, an increase of MFS compared to GLWD is observed over southern regions of the basin mainly over Llanos de Moxos (up to $45 \%$ more over some pixels) and along the Negro and Branco rivers.
Table 3. Proportions of maximal fractions of floodplains (MFF), swamps (MFS) and lakes (\% of the areas of the basin) over the Amazon River basin according to GLWD and PRIMA datasets.

\begin{tabular}{lcc}
\hline Flooded areas & GLWD & PRIMA \\
\hline MFF & $2.59 \%$ & $4.22 \%$ \\
MFS & $15.4 \%$ & $7.97 \%$ \\
Lakes & \multicolumn{2}{c}{$0.79 \%$} \\
Total & $18.8 \%\left(1.17 \times 10^{6} \mathrm{~km}^{2}\right)$ & $12.9 \%\left(0.80 \times 10^{6} \mathrm{~km}^{2}\right)$ \\
\hline
\end{tabular}

To summarize, combining floodplains and swamps, the total maximal fractions in PRIMA are lower on average over the Amazon River basin when compared to GLWD (Table 3). Estimates over Central Amazon were performed by Hess et al. (2003) for the flood period May-August 1996 where water surfaces have been differentiated and classified. We sum the two classes "Non vegetated-flooded" and "Non woody-flooded" for comparison with our "Floodplains" class and "Woody-flooded" class is considered to be equivalent to 
Table 4. Maximal areas in floodplains $\left(\mathrm{km}^{2}\right)$ from satellite estimates (Hamilton et al., 2002; Hess et al., 2003) and the two datasets GLWD and PRIMA. Number in brackets is the relative error (in \%) between the datasets and the estimates.

\begin{tabular}{lclcrrr}
\hline Region & Lon & Lat & Hamilton et al. (2002) & Hess et al. (2003) & GLWD & PRIMA \\
\hline Central Amazon & $72.0^{\circ} \mathrm{W}: 54.0^{\circ} \mathrm{W}$ & $8.00^{\circ} \mathrm{S}: 0.00^{\circ} \mathrm{S}$ & - & $277440^{*}$ & $173395^{*}(-37.5)$ & $231418^{*}(-16.6)$ \\
Mainstem of the Amazon & $70.0^{\circ} \mathrm{W}: 52.0^{\circ} \mathrm{W}$ & $2.00^{\circ} \mathrm{S}: 5.00^{\circ} \mathrm{S}$ & 97360 & - & $6245(-93.6)$ & $69862(-28.2)$ \\
Llanos de Moxos & $68.0^{\circ} \mathrm{W}: 61.0^{\circ} \mathrm{W}$ & $16.0^{\circ} \mathrm{S}: 12.0^{\circ} \mathrm{S}$ & 92094 & - & $5217(-94.3)$ & $64879(-29.6)$ \\
Roraima & $61.5^{\circ} \mathrm{W}: 59.0^{\circ} \mathrm{W}$ & $2.25^{\circ} \mathrm{N}: 4.50^{\circ} \mathrm{N}$ & 16530 & - & $4466(-73.0)$ & $19168(+16.0)$ \\
\hline
\end{tabular}

* Swamps are included.

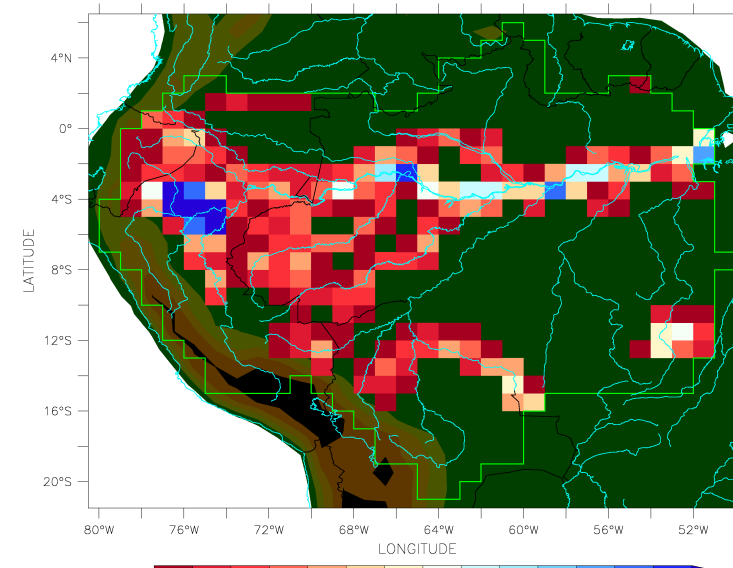

(a)
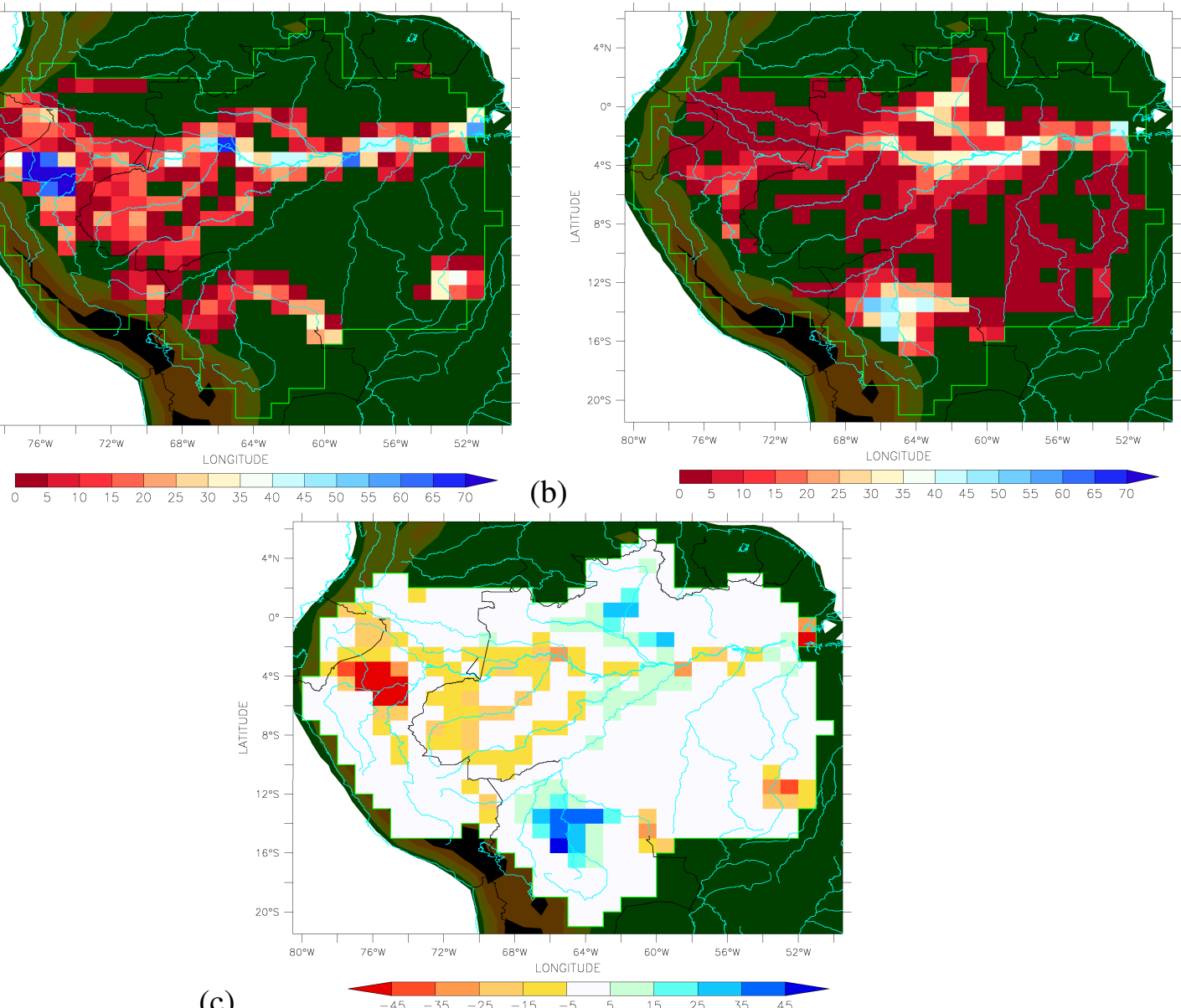

(c)

Fig. 5. Maximal fraction of swamps within the mesh (\% of the mesh area) over the Amazon River basin from (a) GLWD and (b) PRIMA. (c) Differences between (b) and (a). Dark green and brown colors indicate the topography of the region. For topographic scale, see Fig. 2.

"Swamps". On average over the Central Amazon, PRIMA shows an underestimation of less than $20 \%$ of total MFF and MFS compared to Hess et al. (2003)'s estimates whereas GLWD underestimation is near by $40 \%$ (Table 4). Moreover, according to Hess et al. (2003), flooded forest (i.e. swamps) constituted nearly $70 \%$ of the entire wetland area during high water period in this region. The distribution of swamps according to PRIMA is close to this estimate with a value of $61 \%$ whereas GLWD largely overestimates it (95\%).
Figure 6 shows a comparison in MFF and MFS between Hess et al. (2003)'s estimates, GLWD and PRIMA datasets in three points over the main stem of the Amazon River. MFF with GLWD is systematically underestimated throughout the main stem whereas PRIMA is in better agreement with estimates even if MFF remains lower than the estimates by Hess et al. (2003). MFS in PRIMA is well distributed at Curuai (about $20 \%$ ) and Cabaliana (about $40 \%$ ) but for the western region of the main stem, GLWD gives much higher MFS 


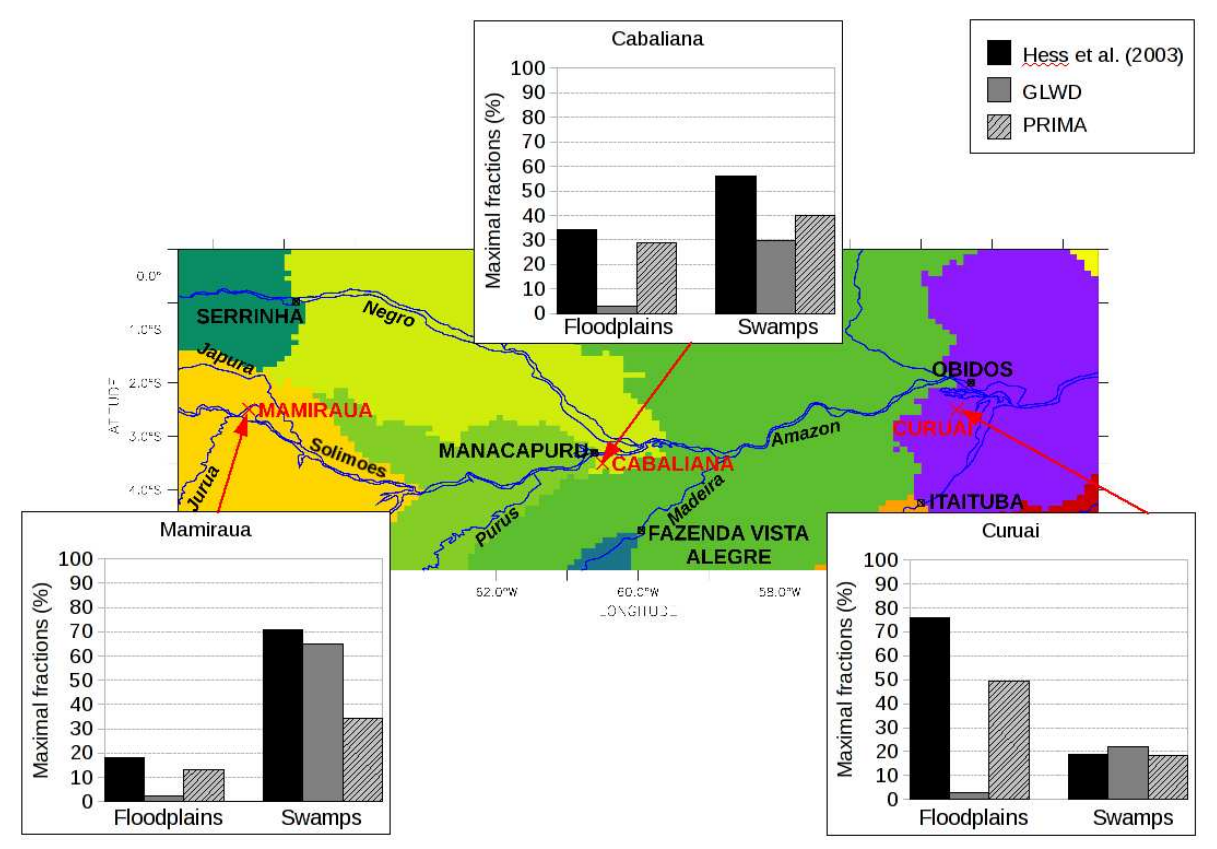

Fig. 6. Comparison of MFF and MFS to Hess et al. (2003)'s observations in different parts of the main stem: Mamiraua near Tefé, Cabaliana near Manacapuru and Curuai near Óbidos. Floodplains from Hess et al. (2003) are considered as the sum of "Non vegetated-flooded" and "Non woody-flooded" classes. Swamps are considered as the equivalent of "Woody-flooded" class. Color is used to distinguish the different sub-basins.

(about $65 \%$ ) than PRIMA (about $35 \%$ ) in agreement with estimates (about $70 \%$ ).

\section{Simulated water budget and streamflows over the basin: impact of NCC precipitation corrected by ORE HYBAM}

\subsection{Simulated water budget}

Water balance analysis led to many estimates from models, reanalysis and, subsequently, measurements of fluxes. A non-exhaustive list of the annual values from some estimates in the literature (mainly from Large Scale BiosphereAtmosphere Experiment in Amazonia, LBA, measurements) is given in Table 5 in average over the Amazon River basin and in different regions of the basin. In comparison, results from simulations ORCH1 (ORCHIDEE forced by NCC) and ORCH2 (ORCHIDEE forced by NCC corrected by ORE HYBAM precipitation) are shown. According to the different estimates, the water budget components over the whole basin are about $6.2 \pm 1.1 \mathrm{~mm} \mathrm{~d}^{-1}$ in precipitation $P, 3.9 \pm 0.7 \mathrm{~mm} \mathrm{~d}^{-1}$ in evapotranspiration (ET) and $2.99 \mathrm{~mm} \mathrm{~d}^{-1}$ in runoff $(R)$. We note that the uncertainty is high in the estimations in $P$ and $E$ (their standard deviations, calculated from the annual values, are around $1.0 \mathrm{~mm} \mathrm{~d}^{-1}$ ). Runoff is estimated from one value from Callede et al. (2010)'s estimate with an error of $6 \%$. Moreover, according to Marengo (2006), the different estimates of areas of the Amazon River basin generate uncertainty in the estimations of runoff at the mouth of the Amazon. Thus, an uncertainty also exists in comparison with simulated runoff. In the model, it is computed from a total surface of basin equal to $5853804 \mathrm{~km}^{2}$ (Fekete et al., 1999) which is lower $(-1.8 \%)$ than Callede et al. (2010)'s estimate $\left(5961000 \mathrm{~km}^{2}\right)$. Precipitation over the whole basin is about $5.6 \mathrm{~mm} \mathrm{~d}^{-1}$ according to NCC. It is underestimated when compared to the average value of the estimations. Furthermore, it is also lower than the median of the observations $\left(5.9 \mathrm{~mm} \mathrm{~d}^{-1}\right)$. NCC value is higher than GPCP estimate $\left(5.2 \mathrm{~mm} \mathrm{~d}^{-1}\right)$, equal to CMAP but underestimated when compared to the five other estimates. ORE HYBAM data $\left(6.0 \mathrm{~mm} \mathrm{~d}^{-1}\right)$ is closer to the average value and the median of the estimations. It is equal to CRU average value and close to the estimates by Marengo (2005) $\left(5.8 \mathrm{~mm} \mathrm{~d}^{-1}\right)$ and LW $\left(5.9 \mathrm{~mm} \mathrm{~d}^{-1}\right)$. Simulated ET over the whole basin (about $2.8 \mathrm{~mm} \mathrm{~d}^{-1}$ ) seems to be underestimated when compared to the average value given by Da Rocha et al. (2009). ET variation between the two simulations is not significant. ET is more limited by the amount of incident energy, which is the same in both simulations, rather than by precipitation change. The resulting simulated runoff at the mouth of the Amazon is underestimated by $6 \%$ compared to Callede et al. (2010)'s estimate when NCC precipitation is used. The correction by ORE HYBAM data leads to an overestimation of $R$ by $8.4 \%$. If we consider that ORE HYBAM precipitation is closer to the observations than NCC, the overestimation of $R$ is mainly due to the low 


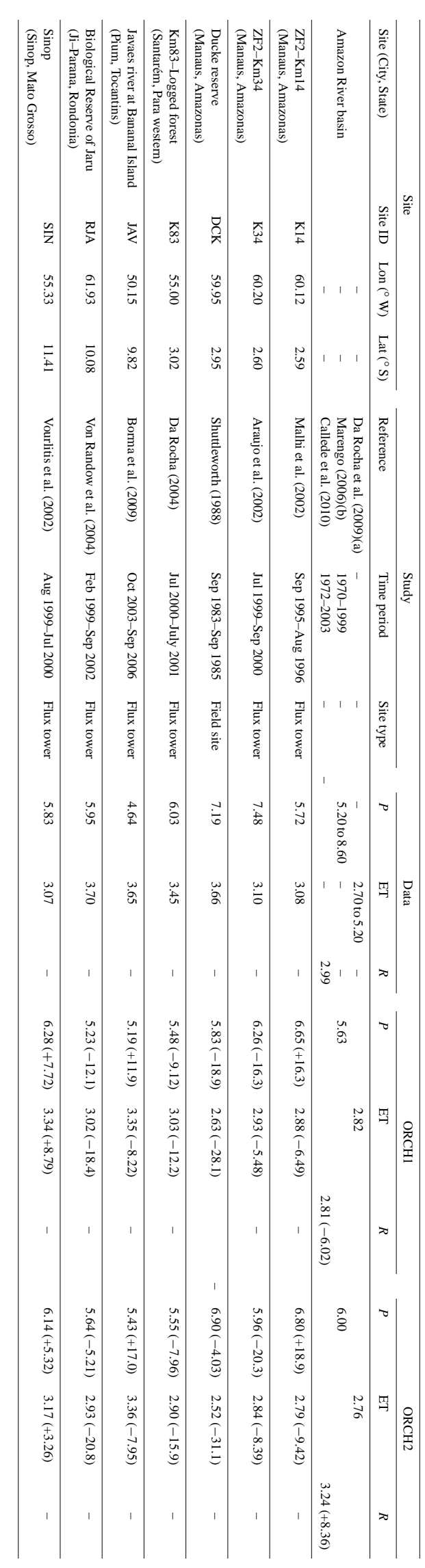

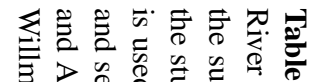

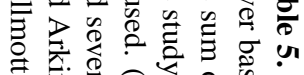

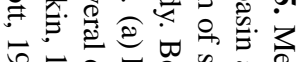

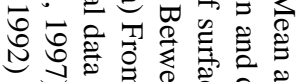

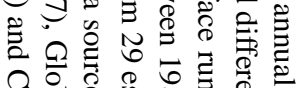

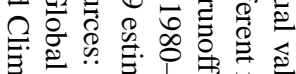

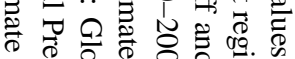
중 융. 훙 $\frac{0}{2} 0$ 语.

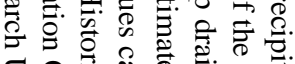
$\subseteq \Omega$

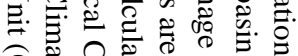
त्兀

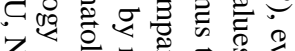
Z

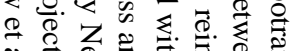

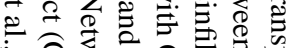

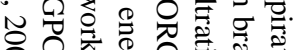

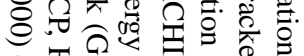

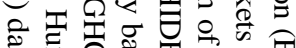

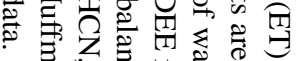

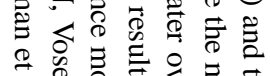
$\because \&$ के

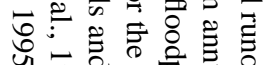

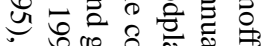

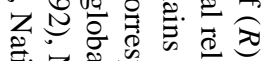
긍 记苍黄

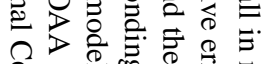
९ी

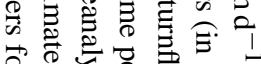
के

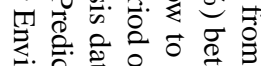

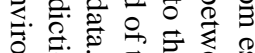

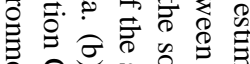
कृ 记

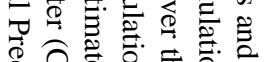

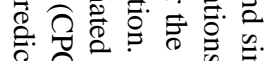

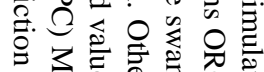

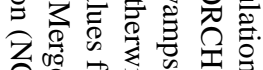

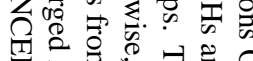

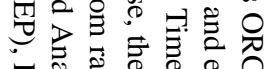

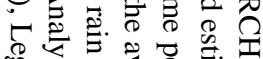
io 营敌产

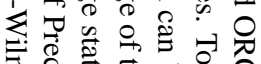

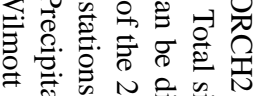

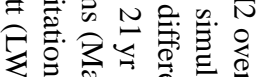

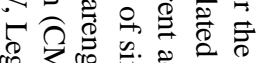

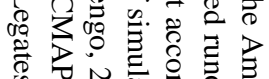

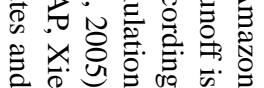


Table 6. Comparison of the mean annual values (all in $\mathrm{mm} \mathrm{d}^{-1}$ ) of precipitation $(P)$, transpiration $\left(T_{v}\right.$ ) and evaporation of water over the leaves $\left(E_{v}\right)$ between measurements by Shuttleworth (1988) near Manaus (Ducke Reserve, see Table 5 for the coordinates) and results from the two simulations ORCH1 and ORCH2, over the mean time period September 1983-September 1985. Values between brackets and $r^{2}$ are, respectively the mean annual relative error $(\%)$ and the coefficient of correlation between simulation and observation.

\begin{tabular}{lllllllll}
\hline & \multicolumn{2}{c}{$P$} & & \multicolumn{2}{c}{$E_{v}$} & & \multicolumn{2}{c}{$T_{v}$} \\
\cline { 2 - 3 } & $\mathrm{mm} \mathrm{d}^{-1}(\%)$ & $r^{2}$ & & $\mathrm{~mm} \mathrm{~d}^{-1}(\%)$ & $r^{2}$ & & $\mathrm{~mm} \mathrm{~d}^{-1}(\%)$ & $r^{2}$ \\
\hline Shuttleworth (1988) & 7.19 & - & & 0.91 & - & & 2.75 & - \\
ORCH1 & $5.83(-18.9)$ & 0.66 & & $1.61(+76.9)$ & 0.61 & & $0.93(-66.2)$ & 0.71 \\
ORCH2 & $6.90(-4.03)$ & 0.71 & & $1.16(+27.5)$ & 0.73 & & $1.27(-53.8)$ & 0.77 \\
\hline
\end{tabular}

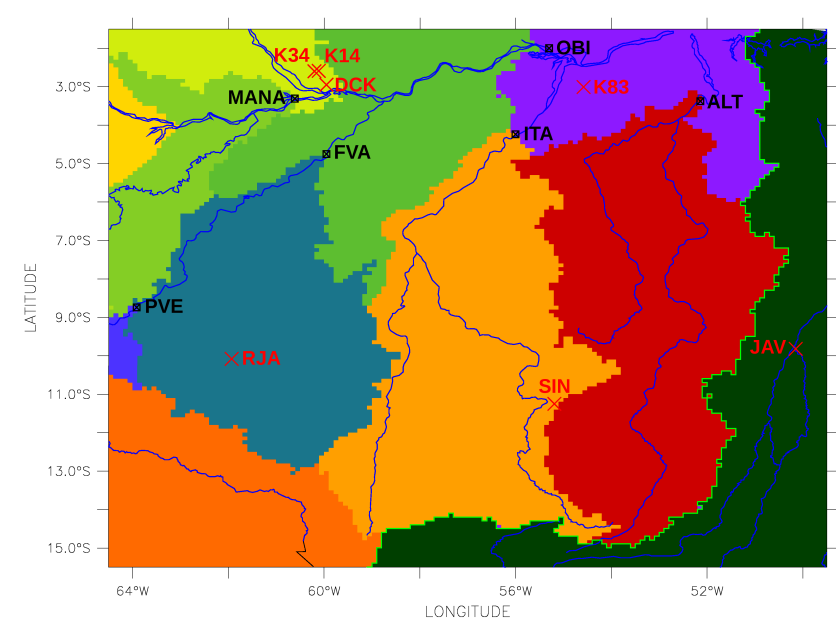

Fig. 7. Map of locations of flux towers stations (in red). See Table 5 for the coordinates of the stations. Color is used to distinguish the different sub-basins. For topographic scale, see Fig. 2.

ET simulated in the model. Simulated $P$ and ET are also compared with measurements (Table 5) from six LBA flux towers and one field site. They are located along the main stem of the Amazon River and over the south-eastern part of the basin (see Fig. 7 for the localization). The results confirm the underestimation in simulated ET for both simulations in the central region of the basin (K14, K34, DCK and K83) and in the south (RJA and JAV). The underestimation at JAV is only $8 \%$ but may be more since $P$ in the model is high compared to observation $(+12$ to $+17 \%)$. Moreover, the low underestimation at JAV and the slight overestimation at SIN (+3 to 9\%) in ET compared to measurements occur in a region facing deforestation. However, in this region, the tropical forest covers $98 \%$ of the grid cell area in the model, whereas the measurements have been performed over a transitional tropical forest. Thus, since ORCHIDEE does not take into account deforestation, the comparison with observation in this region may be biased where simulated ET can be overestimated.
Regarding the underestimation in ET near Manaus, measurements of precipitation and ET are available for two years (September 1983-September 1985) (Shuttleworth, 1988). Moreover, evaporation over leaves $\left(E_{v}\right)$ and transpiration $\left(T_{v}\right)$ data are distinguished. Table 6 shows a comparison of the annual rate of these variables between the two simulations and observations. First, the results in precipitation show an underestimation in annual rate between observations and both simulations. However, underestimation is lower $(-4 \%)$ when NCC is corrected by ORE HYBAM data. Moreover, a better accuracy in variability is found compared to measurements $\left(r^{2}\right.$ of ORCH1 and ORCH2 are, respectively 0.66 and 0.71 ). Both forcings give less precipitation than observed at the end of 1984 and particularly in December (Fig. 8a). Then, ORCH2 is in better agreement with measurements during the dry period. During the next wet period in 1985, the variability of precipitation is not well represented in both simulations. ORE HYBAM overestimates precipitation at the end of the wet 1985 period. The use of daily precipitation from ORE HYBAM database does not change the underestimated simulated ET (Table 5). In fact, the radiative budget is not affected and the energy available to evaporate remains the same. However, the use of ORE HYBAM daily rainfall dataset change the ratio between evaporation of water over the leaves $\left(E_{v}\right)$ and transpiration $\left(T_{v}\right)$. Variation of $E_{v}$ during the time period is improved in $\mathrm{ORCH} 2$ compared to ORCH1 (the coefficients of correlation with observations are, respectively 0.6 and 0.7 with ORCH1 and $\mathrm{ORCH} 2$, Table 6) where a low seasonality was simulated throughout the period (Fig. 8b). Moreover, $E_{v}$ overestimation observed with ORCH1 $(+77 \%)$ is reduced by more than half $(+27.5 \%)$ on average over the period with ORCH2 (Table 6). As $E_{v}$ is reduced, $T_{v}$ increases with $\mathrm{ORCH} 2$ but remains underestimated (respectively about 54 and $66 \%$ for ORCH1 and ORCH2 according to Table 6) throughout the time period (Fig. 8c). However, the seasonal variation is in agreement with observations $\left(r^{2}\right.$ is, respectively 0.7 and 0.8 with ORCH1 and ORCH2 according to Table 6) where dry season and wet season are well differentiated (Fig. 8c). 
(a)
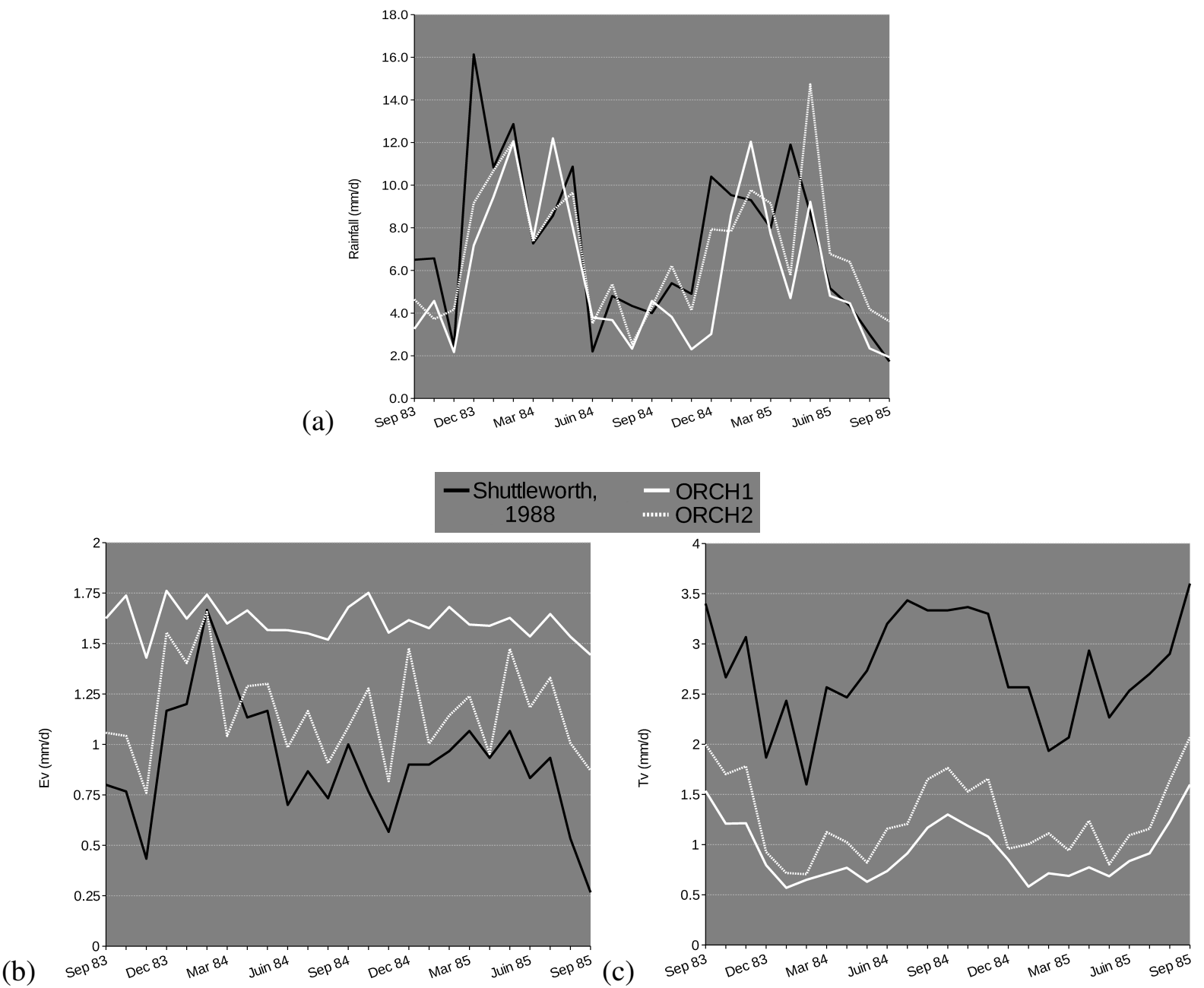

Fig. 8. Comparison of times series of (a) precipitation $(P)$, (b) evaporation of water over the leaves $\left(E_{v}\right)$ and (c) transpiration $\left(T_{v}\right)($ all in $\mathrm{mm} \mathrm{d}^{-1}$ ) between the two simulations (ORCH1 and ORCH2) and estimates from Shuttleworth (1988) near Manaus (Ducke Reserve), over the period September 1983-September 1985.

The precipitation over the Amazon River basin is improved by the use of ORE HYBAM daily dataset. However, ET does not change between the two simulations and remains underestimated compared to observations. This discrepancy may be attributed to the low transpiration simulated by the model that has been pointed out at Manaus. In ORCH2, the resulting simulated runoff at the mouth of the Amazon is consequently overestimated. In the next section, the annual simulated streamflow variation will be studied in the main sub-basins of the Amazon. Moreover, results in streamflow will be discussed when the observations of precipitation and floodplains/swamps distribution are implemented in the forcing of the model.

\subsection{Simulated river discharge at Óbidos and over the sub-basins of the Amazon River}

The mean annual streamflow estimated at the mouth of the Amazon River basin is about $206 \times 10^{3} \mathrm{~m}^{3} \mathrm{~s}^{-1}$ $\left(2.99 \mathrm{~mm} \mathrm{~d}^{-1}\right)$ with an error of $6 \%$ due to the method, for a total area of $5961000 \mathrm{~km}^{2}$ and the time period 1972-2003 (Callede et al., 2010). Simulated streamflow is given at the pixel of the routing network corresponding to the mouth of the basin of a total surface equal to $5853804 \mathrm{~km}^{2}$ in the model (Fekete et al., 1999). According to ORCH1, simulated streamflow at the mouth is underestimated $\left(191 \times 10^{3} \mathrm{~m}^{3} \mathrm{~s}^{-1}\right)$ compared to Callede et al. (2010)'s estimates $(-7.42 \%)$ whereas with ORCH2, an overestimation is found $\left(220 \times 10^{3} \mathrm{~m}^{3} \mathrm{~s}^{-1}\right.$ i.e. $\left.+6.56 \%\right)$. We note that the differences in streamflow between simulation and observation are of the same order than the estimated error in observation. The increase of about $15 \%$ in streamflow of the 
(a)

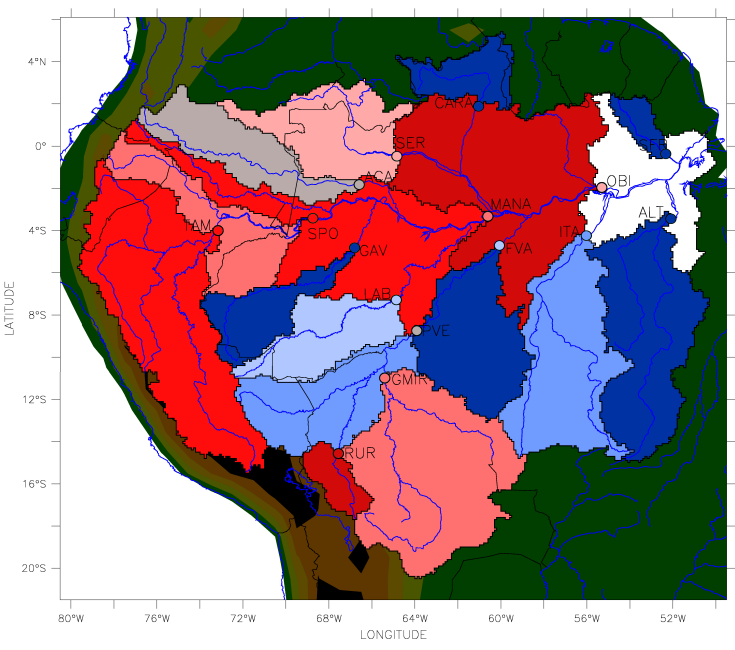

(b)

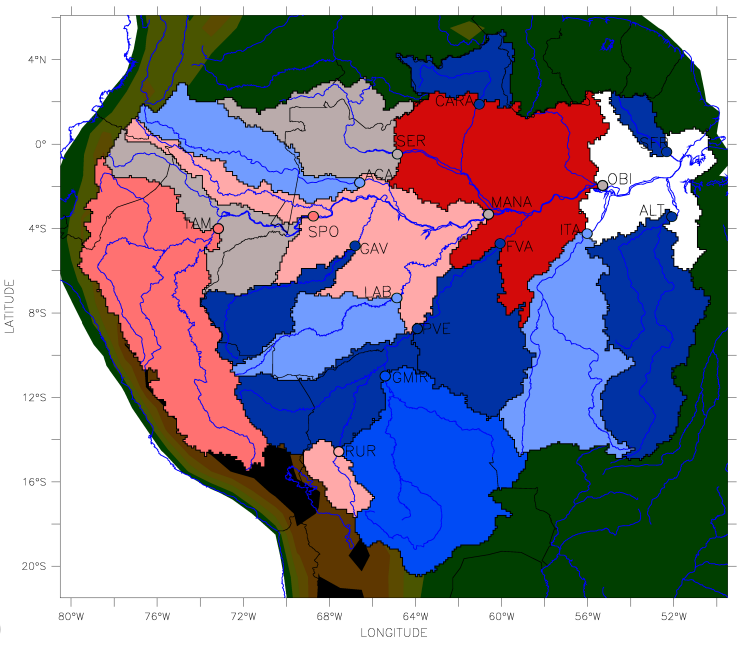

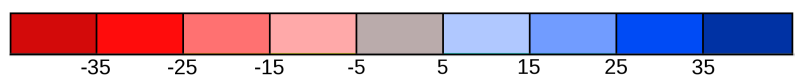

Fig. 9. Mean relative error of Qmean (\%) between simulations - (a) ORCH1, (b) ORCH2 - and observation over the time period 1980-2000. The color indicates the sign of the error: red is negative error, blue is positive error and grey is very low error. The error is represented for the different stations (colored circles) and their associated sub-basins (same color than the corresponding station). Five residual basins are also represented: SPO*, MANA*, OBI*, PVE* and FVA*. Qmean of each residual basin is the difference between the downstream and the upstream station(s) Qmean. Thus, the color of the residual basin can be different from the color of the downstream station. For topographic scale, see Fig. 2.

Amazon between ORCH1 and ORCH2 is mainly due to the increase in precipitation $(+6.75 \%)$ (ET did not change) when NCC data is corrected by ORE HYBAM. At the Óbidos station, which is the nearest gauged station from the outlet of the basin, mean annual simulated streamflow with ORCH1 is highly underestimated $(-15 \%)$ compared to ORE HYBAM discharge measurements, whereas with $\mathrm{ORCH} 2$ it is in good agreement with ORE HYBAM $(-0.25 \%)$ (Table 7$)$. Thus, between Óbidos and the mouth of the Amazon, a large quantity of water, overestimated in both simulations, comes from the south-eastern river basins (Xingu and Tapajos Rivers) as found at Itaituba $(+20 \%)$ and Altamira (more than $+90 \%$ ) according to Table 7 (see Fig. 2 and Table 2 for localization of the stations).

At Óbidos station, about $20 \%$ of discharge comes from southern basins (Fazenda Vista Alegre), 20\% from northern basins (Acanaui, Serrinha, Caracarai), $30 \%$ from western/south-western basins (Sao Paulo de Olivença, Gaviao, Labrea) and $30 \%$ from central residual basins (between Sao Paulo de Olivença and Manacapuru - hereafter called "MANA*" - and between Manacapuru and Óbidos hereafter called "OBI*") (Espinoza et al., 2009a) (see Fig. 2 and Table 2 for localization of the stations). With simulation ORCH1, the underestimation of streamflow at Óbidos is mainly due to the low streamflow over western/southwestern regions of the basin (near $-35 \%$ at Tamshiyacu) and over the two central residual basins (between -25 to more than $-35 \%$ ) (Fig. 9a). The streamflow coming from the south is close to the observations but it is a compensation between the overestimation at Rurrenabaque and GuajaraMirim and the underestimation over the two southern residual basins (hereafter called "PVE*" and "FVA*"). Simulated streamflow in northern stations like Acanaui and Serrinha is close to the observations and an overestimation is observed over the northernmost region of the basin at Caracarai. The correction of NCC precipitation by ORE HYBAM data leads to a decrease of the error with observation over Andean sub-basins ( $-24 \%$ at Tamshiyacu) and over the residual basin of MANA* where the precipitation has been significantly increased (Fig. 9b). Simulation of streamflow over the residual basin of OBI* is not improved. It can be due to the lack of available rainfall gauges for kriging over this region (see Fig. 1 of Espinoza et al., 2009b). The overestimation of streamflow over all the southern sub-basins (except Rurrenabaque) by $25 \%$ to more than $35 \%$, mainly due to the increase of the rainy spots, leads to an excess of water at Fazenda Vista Alegre. Consequently, simulated streamflow from $\mathrm{ORCH} 2$ at Óbidos station, close to the observations, is a result of a compensation between southern and western/south-western regions.

The observed streamflow at Óbidos has a pronounced seasonality during the year (Fig. 10a). Flow is highest, on average, during May and June with a maximum value of about $230 \times 10^{3} \mathrm{~m}^{3} \mathrm{~s}^{-1}$. Then, a decrease occurs during five months until the low-flow in November (near $\left.103 \times 10^{3} \mathrm{~m}^{3} \mathrm{~s}^{-1}\right)$. Simulated streamflow is time shifted in 


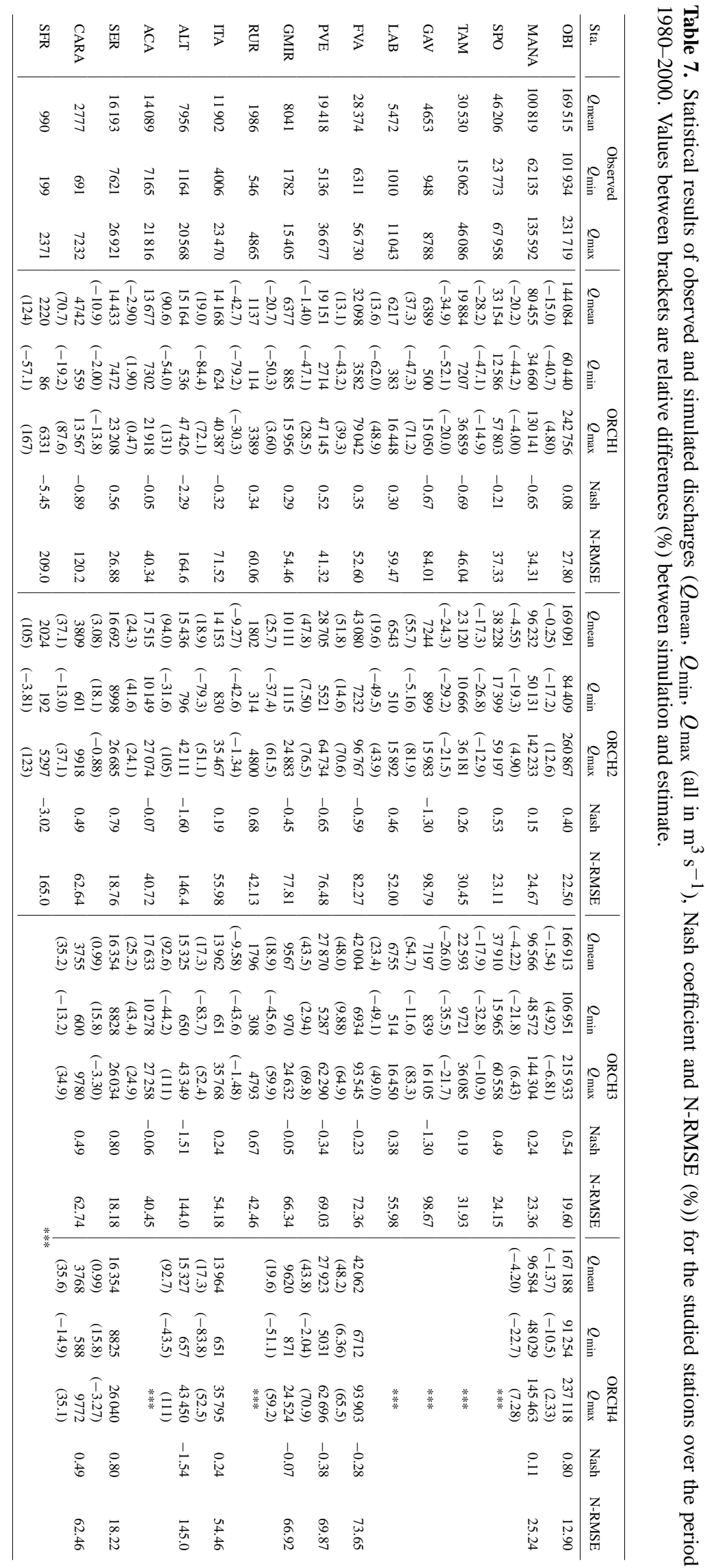




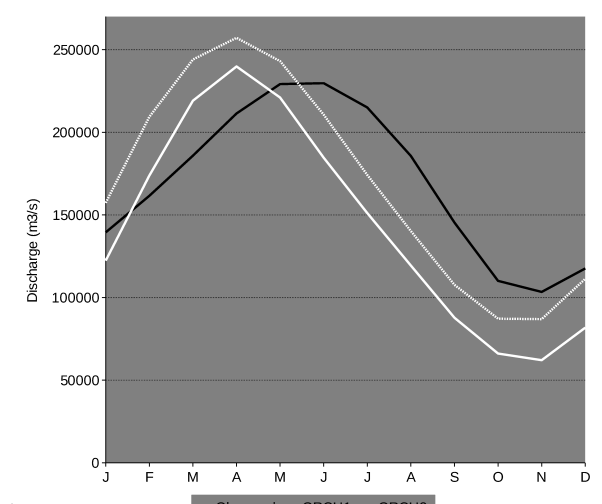

(a)

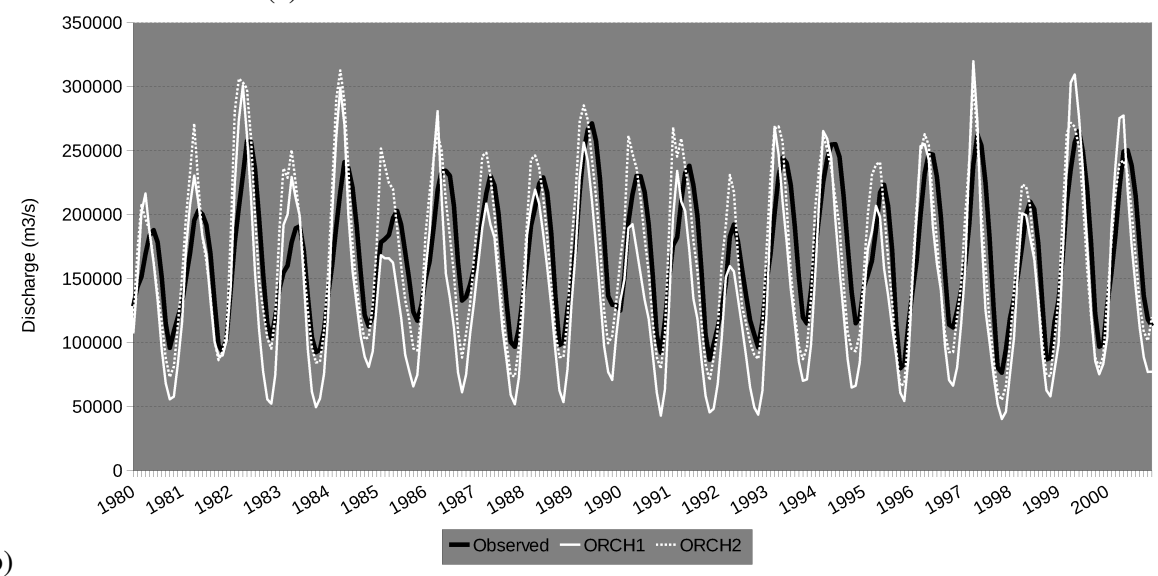

Fig. 10. Mean monthly discharge $\left(\mathrm{m}^{3} \mathrm{~s}^{-1}\right)$ at Óbidos for simulations ORCH1 and ORCH2 compared to observations. (a) Mean annual seasonality and (b) interannual variation over the time period 1980-2000.

both simulations compared to the observations (Fig. 10a). In fact, according to cross-correlation statistic (see Appendix for more details), correlation between simulated and observed discharges would be optimal if a time lag of 1 month was applied $\left(d_{t}=1\right.$ and $r_{\text {cross }}=0.91, r_{\text {cross }}=0.93$ for ORCH1 and $\mathrm{ORCH} 2$, respectively). However, Nash coefficient (see Appendix for more details) is increased when ORCHIDEE is forced by NCC precipitation corrected by ORE HYBAM (0.08 and 0.40 , respectively for ORCH1 and ORCH2 according to Table 7) indicating a significant improvement of the simulation in streamflow at Óbidos when ORE HYBAM precipitation is used. The simulated interannual variation in streamflow is better captured with $\mathrm{ORCH} 2$ according to the coefficient of variation of the root mean squared error (see Appendix for more details) which is lower $(22.5 \%)$ than with ORCH1 $(28 \%)$. The simulated low-flow is improved ( $-17 \%$ with $\mathrm{ORCH} 2$ compared to $-41 \%$ with ORCH1) but remains underestimated for most years whereas simulated high-flow is slightly overestimated with ORCH2 $(+5 \%)$ even more during some dry years $(1981,1985,1992)$ (Fig. 10b).

Figure 11 depicts all the simulated seasonal cycles for both simulations at the sixteen stations across the Amazon River basin and are compared to the observed seasonality. Northern stations show an underestimation in high-flow in the western part (Acanaui and Serrinha) and an overestimation in the eastern part (Caracarai and Sao Francisco). Low-flow is underestimated everywhere except in the north at Acanaui and Serrinha. The improvement of the seasonal cycles at Tamshiyacu and Sao Paulo de Olivença is pointed out when precipitation is corrected by ORE HYBAM data. The underestimation in low-flow is reduced by about $50 \%$. The Nash coefficient becomes positive in these stations, reaching 0.5. This mainly contributes to the increase in low flow at Óbidos with ORCH2 compared to ORCH1 and becomes in better agreement with observations. Moreover, the increase in precipitation in the north-western part of the basin induces a better seasonality. At station Acanaui, no change in Nash coefficient is shown but at Serrinha, the seasonality is well captured when compared to observations (Nash coefficient reaches about 0.80). Interannual variation of streamflow at this station is also well simulated as shown in Fig. 12 (N-RMSE for ORCH1 and ORCH2 are, respectively about $27 \%$ and $19 \%$ ). A better capture of high-flow with $\mathrm{ORCH} 2$ is shown $(-1 \%$ of mean annual relative error with observations) and high-flow of each year from 1986 to 1993 is in better agreement with observations than with ORCH1 

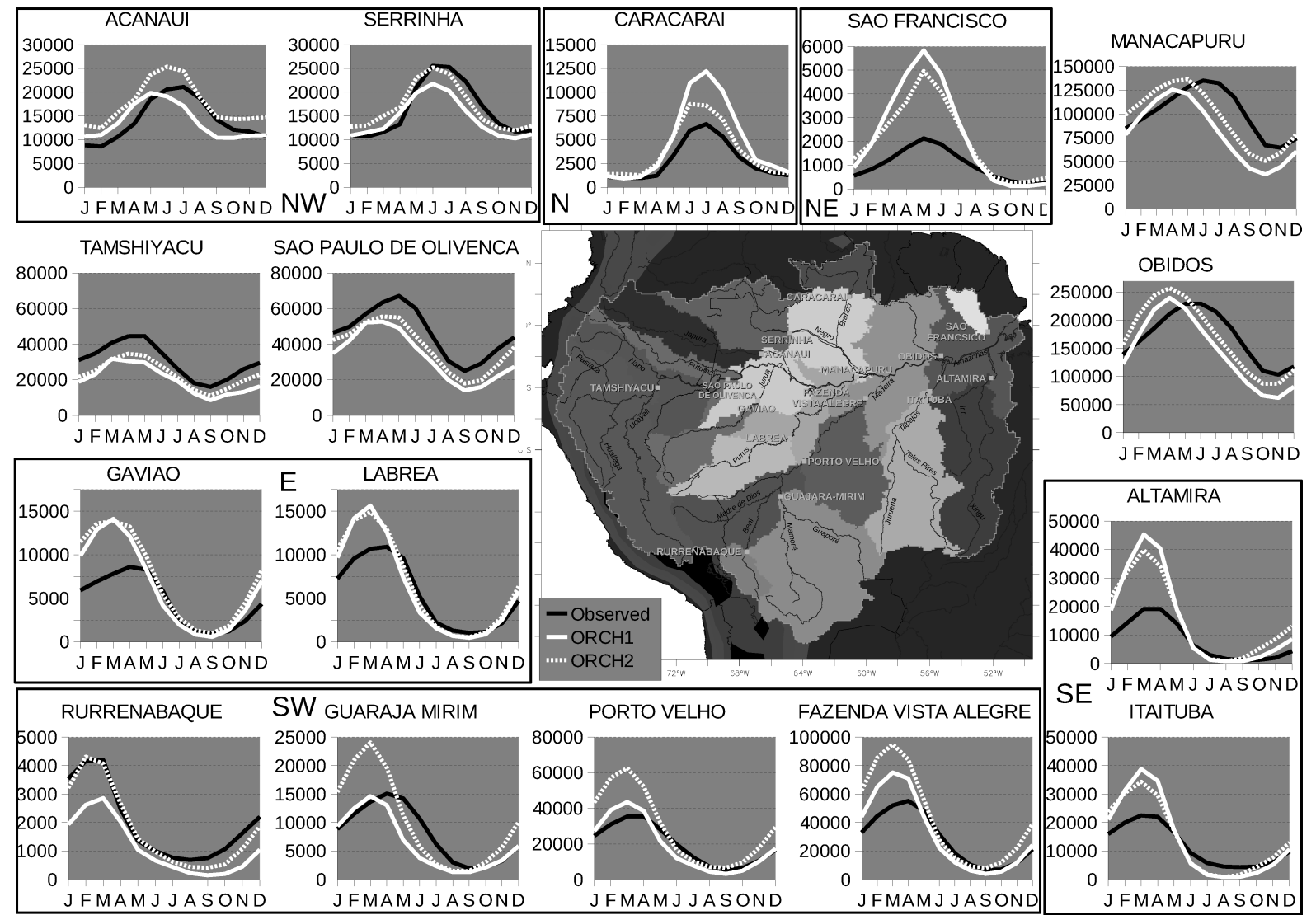

Fig. 11. Mean seasonal discharges $\left(\mathrm{m}^{3} \mathrm{~s}^{-1}\right)$ over the sub-basins for simulations $\mathrm{ORCH} 1$ and $\mathrm{ORCH} 2$ compared to observations, over the mean period 1980-2000. The stations are organized according their locations - North (N), North-East (NE), East (E), South-East (SE), South-West (SW), West (W) and North-West (NW).

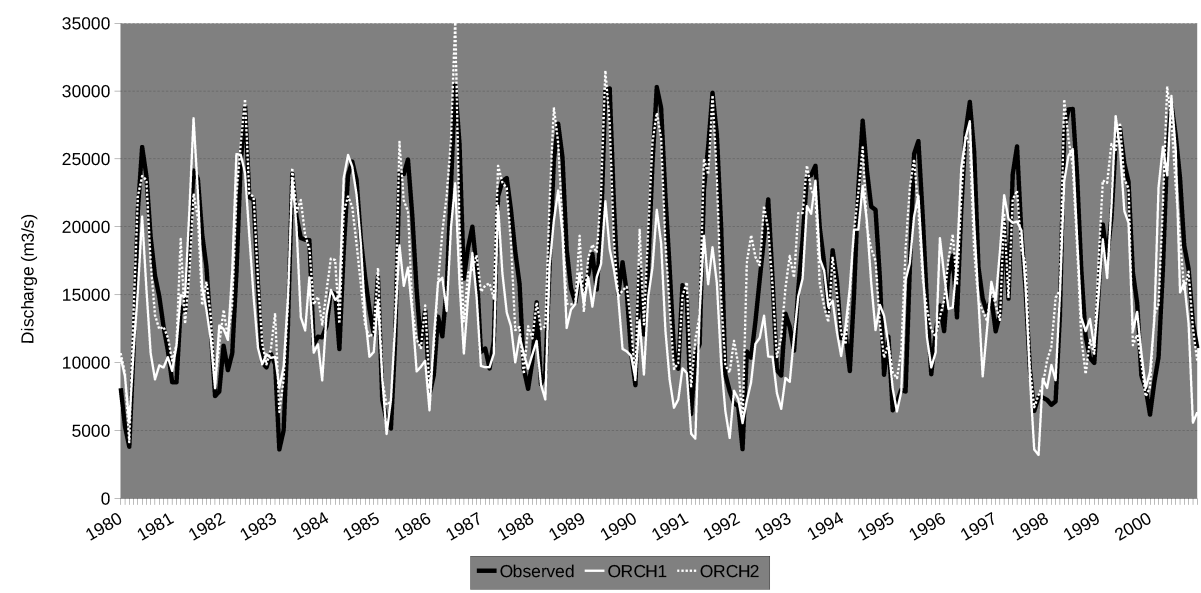

Fig. 12. Interannual variation of monthly discharge $\left(\mathrm{m}^{3} \mathrm{~s}^{-1}\right)$ at Serrinha for simulations $\mathrm{ORCH} 1$ and $\mathrm{ORCH} 2$ compared to observations, over the time period $1980-2000$.

where they are systematically underestimated. In northern and north-eastern regions, simulated streamflow is improved (high-flow indeed) by the decrease in precipitation at Caracarai and Sao Francisco. Interannual variation of highflow is better captured at Caracarai with ORCH2 (Fig. 13): the coefficient of correlation with observations is about 0.86 compared to 0.74 with ORCH1. Improvements are less pronounced for stations in south-eastern regions (Altamira and Itaituba) where a decrease in precipitation was introduced. Concerning southern stations, simulated streamflow 


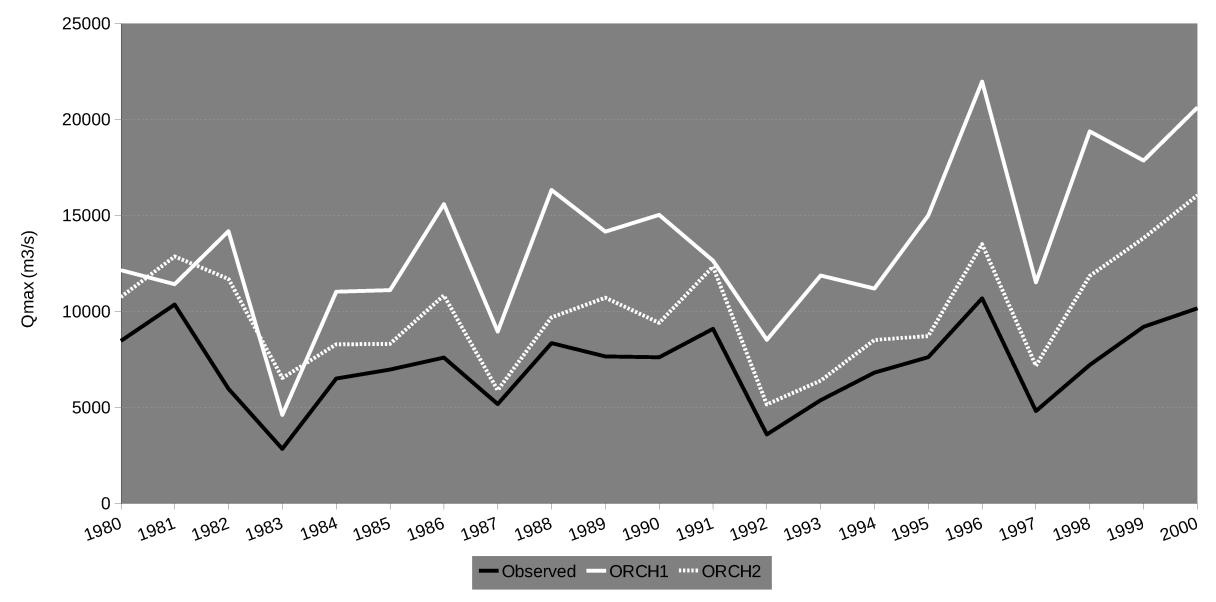

Fig. 13. Interannual variation of maximal monthly discharge $\left(\mathrm{m}^{3} \mathrm{~s}^{-1}\right)$ at Caracarai for simulations $\mathrm{ORCH} 1$ and $\mathrm{ORCH} 2$ compared to observations, over the time period 1980-2000.
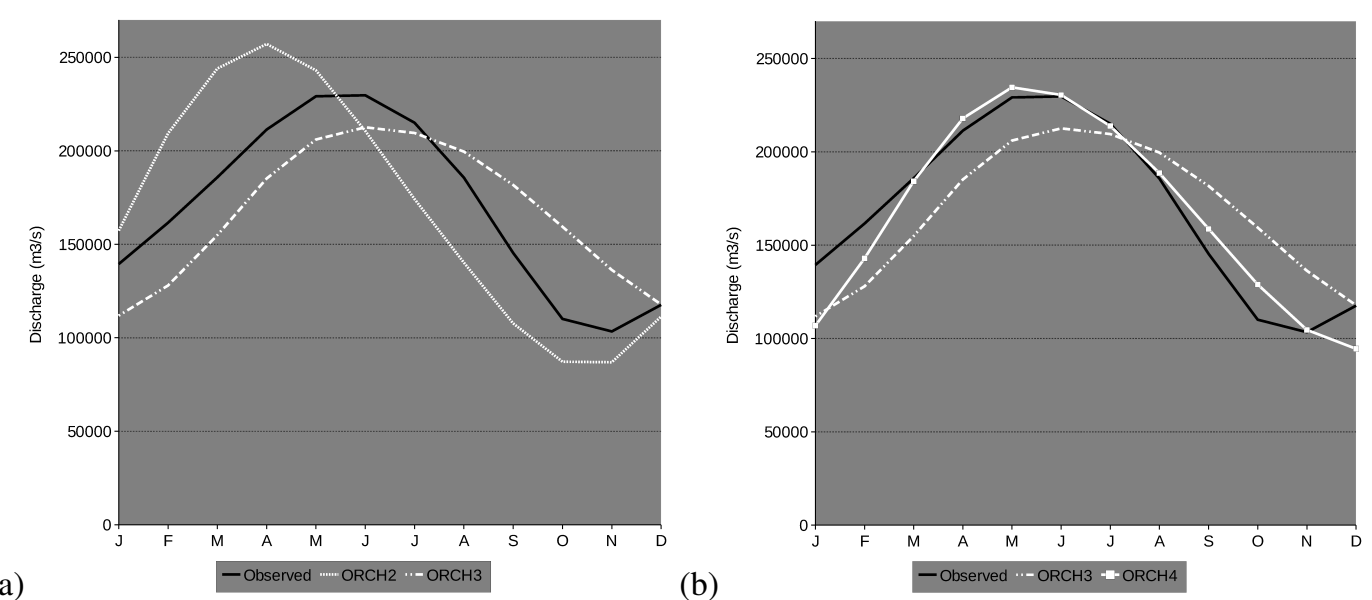

Fig. 14. Mean monthly seasonal discharge $\left(\mathrm{m}^{3} \mathrm{~s}^{-1}\right)$ at Óbidos for simulation ORCH3 compared to (a) ORCH2 and (b) ORCH4. Comparison with observations is shown over the mean time period 1980-2000.

is degraded following the increase in precipitation. The overestimation in high flow simulated with ORCH1 is accentuated except for Rurrenabaque where streamflow seasonality is well simulated $(-1.3 \%$ of mean annual relative error with ORCH2). One can expect an underestimation in ET by ORCHIDEE over southern regions of the Amazon River basin as far as ORE HYBAM precipitation is satisfactory.

\section{Impact of the new distribution in maximal fractions of floodplains and swamps on river discharge}

\subsection{Discharge at Óbidos and model calibration}

The introduction of a new map of MFF and MFS (simulation ORCH3), improves the seasonality of the streamflow at Óbidos - ORCH3 Nash coefficient is higher (0.54) than
ORCH2 one (0.40) and N-RMSE is lower (19.6 compared to 22.50) according to Table 7. The increase in MFF over the main stem of the Amazon smoothes the increase in streamflow similarly to the observations (Fig. 14a) but delays the high-flow by one month $\left(d_{t}=-1\right.$ and $\left.r_{\text {cross }}=0.90\right)$. In order to improve the timing of the high-flow, a calibration of the time constant of the floodplains reservoir, which was evaluated over the Niger Inner Delta ( $g_{\mathrm{Fd}}=4.0$ days), is performed in simulation ORCH4. The delay is corrected with a value of 2.5 days for the parameter $g_{\mathrm{Fd}}\left(d_{t}=0\right.$ and $\left.r_{\text {cross }}=0.91\right)$ as shown in Fig. 14b, leading to a value of high-flow similar to observation ( $+2 \%$ of error in Qmax). The Nash coefficient is consequently increased $(0.80)$.

The increase in MFF over the region of Llanos de Moxos delays the peak of high-flow to March-April in agreement with observations leading to a better capture of low-flow period from August to November (Fig. 15a). Moreover, 

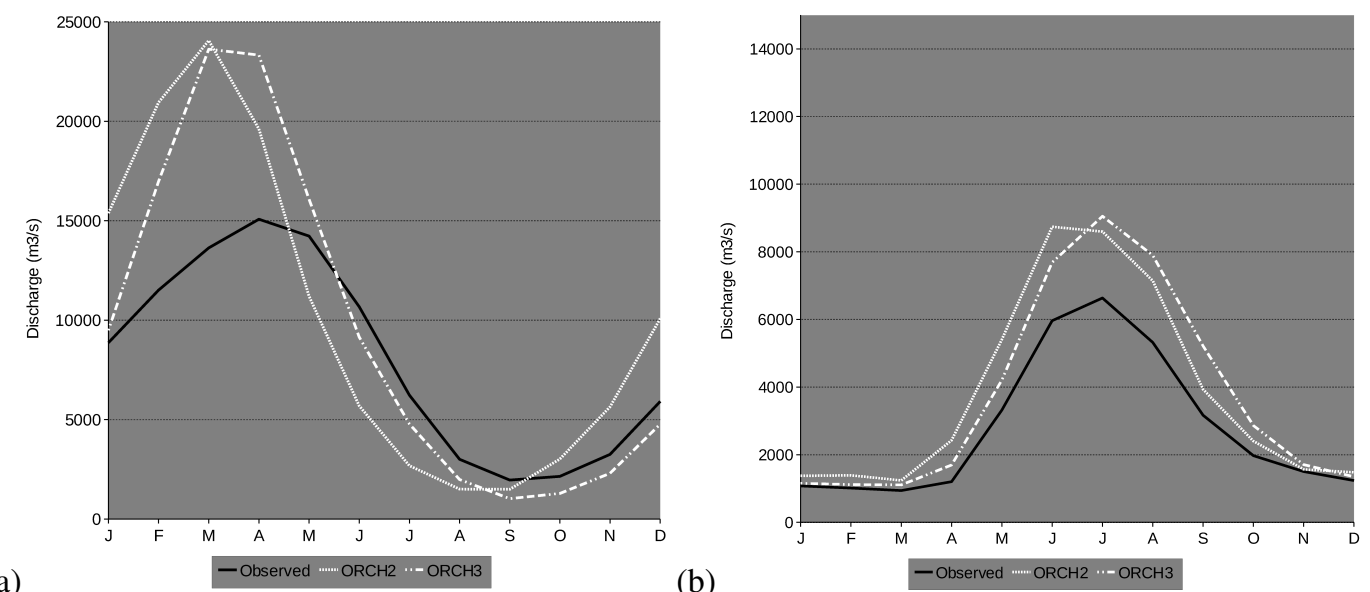

(a)

(b)

Fig. 15. Mean monthly seasonal discharge $\left(\mathrm{m}^{3} \mathrm{~s}^{-1}\right)$ at (a) Guajara-Mirim and (b) Caracarai for simulation ORCH3 compared to ORCH2 and observations, over the mean time period 1980-2000.

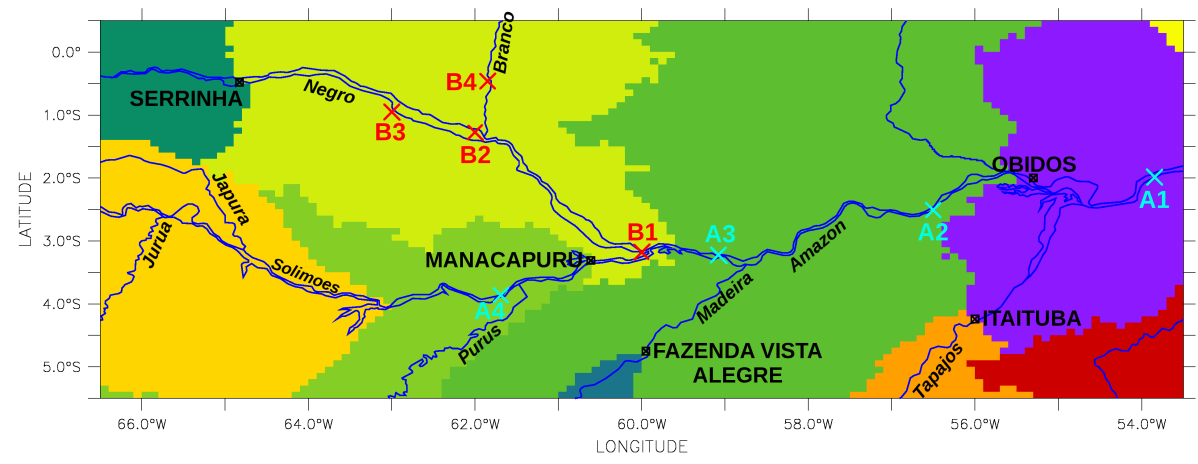

Fig. 16. Map of locations of virtual stations on Topex/Poseidon ground tracks available for the period 1993-2000: 4 locations on the mainstem (ID An with $n=1$ to 4 in light blue) and 4 locations on the Rio Negro-Branco (ID Bn with $n=1$ to 4 in red). See Table 8 for coordinates of the stations. Color is used to distinguish the different sub-basins.

the mean annual streamflow at Guajara-Mirim decreases in ORCH3 (about $500 \mathrm{~m}^{3} \mathrm{~s}^{-1}$ ) due to increased swamps area in PRIMA map. The same effect is simulated inside the basin of the upper Rio Branco with ORCH3. A delay of the peak flow by one month occurs and a better capture of high-flow evolution during June to August is performed (Fig. 15b). The calibration at Óbidos does not change significantly the streamflows at the other stations compared to the previous results obtained with ORCH3 (see Table 7).

\subsection{Simulated water height of the floodplains}

Streamflow seasonality of the Amazon can be highly affected by floodplains distribution mainly between Manacapuru and the mouth, where large amounts of water are transferred through the floodplains (Bonnet et al., 2008). Thus, variations of water height of the floodplains simulated in ORCHIDEE are compared with observations from Topex/Poseidon. Flooded fraction extension cannot be compared with observations as long as the swamps do not have a spatio-temporal variability simulated in ORCHIDEE. That would be an interesting perspective for further development of the model, but high uncertainties exist for this representation according to the poorly known topography in forested areas. Over the period 1993-2000, 8 locations of Topex/Poseidon measurements are distributed along the main stem of the Amazon, the Rio Branco and the Rio Negro (Fig. 16).

Results from simulation ORCH4 are compared to these estimates for the same time period. The effect of the change from the old distribution of the MFF (ORCH2) to the new one (ORCH3) and the effect of the calibration at Óbidos $(\mathrm{ORCH} 4)$ on the simulated water level height is also shown (Table 8). Water height of the floodplains is not directly considered because ORCHIDEE does not take into account the height of the river bed. Then, an index of water height variation is performed for simulation and observations data. The minimal value of the water height during the $8 \mathrm{yr}$ is considered as the height of the river bed and it is consequently subtracted each month to the water level height from the simulated and observed data. 
Table 8. Comparison of the water height index $H_{\text {index }}(\mathrm{m})$ between simulations ORCH2 to ORCH4 and observations, in 4 locations on the mainstem (ID A) and 4 locations on the Rio Negro-Branco (ID B) (see Fig. 16 for locations), for the time period 1993-2000. Monthly mean correlation coefficient $r^{2}$ and monthly standard deviation $\sigma$ are given.

\begin{tabular}{|c|c|c|c|c|c|c|c|c|c|c|c|c|c|}
\hline \multicolumn{3}{|c|}{ Stations } & \multicolumn{4}{|c|}{$\overline{H_{\text {index }}}(\mathrm{m})$} & \multicolumn{2}{|c|}{$r^{2}$} & \multirow[b]{2}{*}{ ORCH4 } & \multicolumn{3}{|c|}{$\sigma(\mathrm{m})$} & \multirow[b]{2}{*}{ ORCH4 } \\
\hline ID & Lat. & Lon. & Observed & $\mathrm{ORCH} 2$ & ORCH3 & $\mathrm{ORCH} 4$ & $\mathrm{ORCH} 2$ & ORCH3 & & Observed & $\mathrm{ORCH} 2$ & ORCH3 & \\
\hline A1 & -1.98 & -53.85 & 2.85 & 75.98 & 8.82 & 6.39 & 0.82 & 0.71 & 0.90 & 1.20 & 44.80 & 4.17 & 3.43 \\
\hline A2 & -2.51 & -56.50 & 4.76 & 66.35 & 51.88 & 36.93 & 0.79 & 0.73 & 0.92 & 1.74 & 37.56 & 26.74 & 20.22 \\
\hline A3 & -3.23 & -59.08 & 7.98 & 43.66 & 22.27 & 14.07 & 0.66 & 0.84 & 0.77 & 3.13 & 24.50 & 12.30 & 7.99 \\
\hline A4 & -3.86 & -61.69 & 7.70 & 40.40 & 14.70 & 9.16 & 0.80 & 0.85 & 0.81 & 3.02 & 22.14 & 7.82 & 4.96 \\
\hline B1 & -3.18 & -60.00 & 7.72 & 19.28 & 10.19 & 6.37 & 0.87 & 0.92 & 0.89 & 3.57 & 10.49 & 5.35 & 3.40 \\
\hline B2 & -1.28 & -62.00 & 5.38 & 3.14 & 2.14 & 1.35 & 0.89 & 0.91 & 0.90 & 3.03 & 1.77 & 1.21 & 0.76 \\
\hline B3 & -1.06 & -63.00 & 3.56 & - & \multicolumn{2}{|c|}{1.21} & - & 0.54 & 0.54 & 2.32 & - & \multicolumn{2}{|c|}{0.78} \\
\hline B4 & -0.46 & -62.00 & 4.32 & 5.06 & 2.19 & 1.37 & 0.72 & 0.74 & 0.73 & 2.59 & 2.91 & 1.23 & 0.77 \\
\hline
\end{tabular}

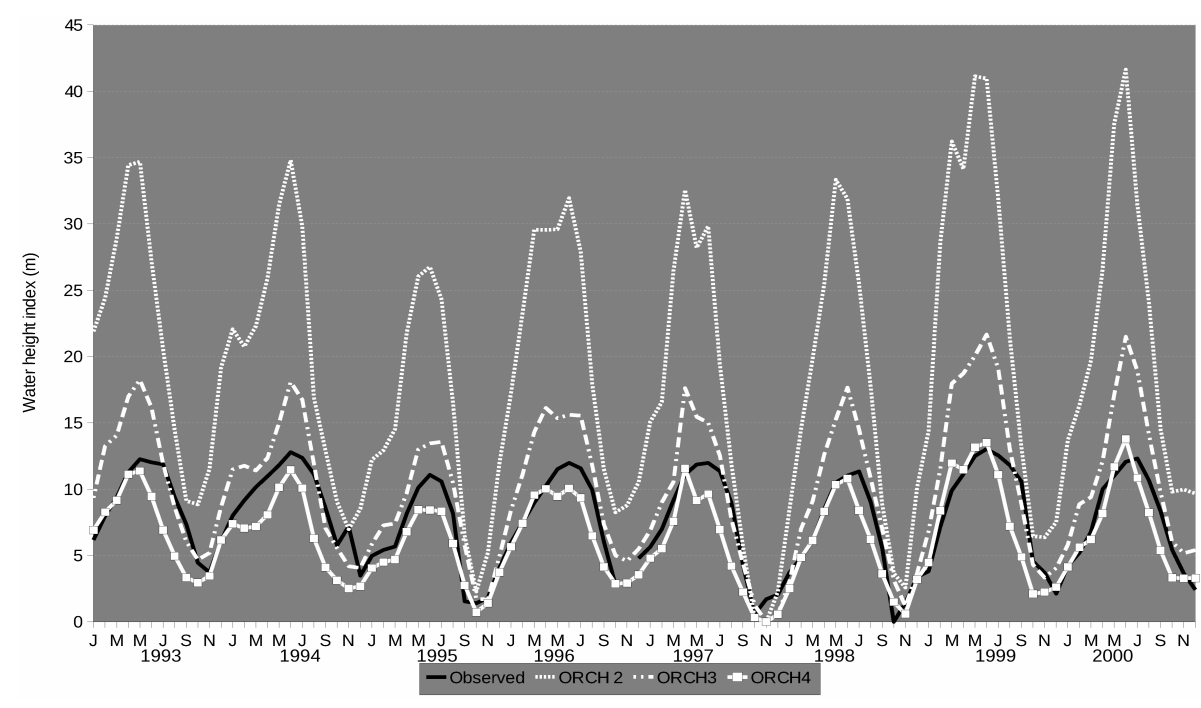

Fig. 17. Interannual variation of monthly water height index $H_{\text {index }}(\mathrm{m})$ at station $\mathrm{B} 1$ (see Fig. 16 for location) on the Rio Negro, for the simulations ORCH2 to ORCH4 compared to the Topex/Poseidon observations, over the time period 1993-2000.

Over the main stem, water height level is highly overestimated at the four stations (A1 to A4) with the old distribution of MFF (ORCH2) according to Table 8. Moreover, the overestimated standard deviation indicates a toohigh variation in simulated water height through the year, despite a good correlation with observations. The new distribution of MFF (ORCH3) increases the rate of MFF over the main stem and logically reduces the water height of the floodplains. The calibration (ORCH4) improves the mean water height for the four stations (Table 8) and gives better correlations with observations (up to 0.92). However, the water height remains overestimated for all the stations, mainly around Óbidos. This is consistent when compared to Fig. 6 where Hess et al. (2003) estimate $25 \%$ more MFF than ORCHIDEE at Curuai near Óbidos. Around Manacapuru (stations A3 and A4), the simulated water height is in better agreement with Topex/Poseidon measurements with a small overestimation. This corroborates the findings by
Hess et al. (2003) who estimate only $5 \%$ more of MFF than ORCHIDEE at Cabaliana near Manacapuru (see Fig. 6).

Over the Rio Negro, the change of the distribution in MFF does not improve the correlation with measurements which is good near the main stem at B1 and B2 (about 0.9) and low at B3 and B4 (between 0.5 and 0.7) (Table 8). We note that no fraction of floodplains were present in the old map at station B3, whereas the new distribution now enables a comparison with observations. The water height is underestimated at all the stations when compared to measurements, for all the simulations except B 1 close to the main stem. In fact, the interannual seasonality of water height of floodplains is well captured at this station with ORCH4 compared to measurements during the eight years (Fig. 17). The old distribution in MFF largely overestimates the water height in flooded areas. 


\section{Summary and final remarks}

In this work, the simulation by ORCHIDEE of discharge values in the main tributaries of the Amazon River basin and in the last gauged station Óbidos has benefited from two major inputs. A first improvement results from the introduction of a comprehensive daily rainfall observations derived from ORE HYBAM dataset, that includes data from upstream regions of the basin, especially in Bolivia, Peru, Ecuador and Colombia that were not taken into consideration in former simulations. Additionally to a good density of rainfall stations, a distribution that takes into account very rainy spots in the Andes or in the North-West contribute to a better reliability of rainfall input. Indeed, the addition of high rainfall in the northwestern equatorial region and in some rainy spots spread along the Andes tends to improve the mean rainfall over the basin $(\mathrm{ORCH} 2)$ that was previously underestimated (ORCH1). Simulated evapotranspiration remains underestimated when using ORE HYBAM rainfall forcing, but the use of daily values in precipitation seems to highly improve the seasonal variation of evaporation of water over the leaves (ORCH2) when compared to Shuttleworth (1988)'s measurements near Manaus. The forcing by ORE HYBAM rainfall results in an increase in streamflow by $15 \%$ at Óbidos (ORCH2) that is more realistic than the previous one (ORCH1) when compared to the observations. However, the amplitude of the annual cycle is still inadequate. The flood is higher than observed at Óbidos, which may be attributed to overestimated high-flow in the southern basins and the low water stage is too low in accordance with low values in the northwestern basins. At a regional scale, ORE HYBAM rainfall forcing considerably improves the discharge in the western basins where the seasonality and the interannual variability are reasonably well captured. This is also observed in the northern basins where the previously overestimated streamflow is reduced. However, streamflow is degraded in some southern basins where simulated evapotranspiration may be too low and the extension of rainy spots exaggerated by our interpolation method. An ongoing work thus aims at defining a better interpolation method, that would allow for a better description of the rainfall in the Andean part of the basin. A more accurate spatial pattern of the rainy spots should reduce the amount of precipitation over the respective sub-basins. In simulation $\mathrm{ORCH} 2$, the extremes in streamflow occur earlier than observed at Óbidos. That is why a second modification has been realized by introducing a new map of maximal fractions of floodplains and swamps in the model (ORCH3). The improvements are especially significant over large areas such as the main stem of the Amazon River and the Llanos de Moxos region.

A better capture of the streamflow seasonality is also found over small basins such as the Branco River at Caracarai. However, for small basins, product quality is probably not sufficient since the spatial resolution of the satellite observation is approximately $25 \times 25 \mathrm{~km}^{2}$ and the error bar on the product is about $10 \%$ (Prigent et al., 2007). Together with a calibration at Óbidos of the time constant of the floodplains reservoir in the model (ORCH4), the change in floodplains/swamps maps has improved the simulated water height of floodplains in the main stem of the Amazon River and corrected the discharge seasonality at Óbidos and in the involved sub-basins. Some extensions of this study can be considered, such as a vegetation map that would introduce the recent extension of deforested areas and finally, a better representation of evapotranspiration in the model. In addition, the improvements performed in the study in the ability of the ORCHIDEE model to represent the hydrological dynamics in the Amazon River basin make this model a powerful tool for studying the impact of climate change scenarios on the river discharge.

\section{Appendix A}

\section{Statistical tools}

Various indicators are used to compare observed and simulated discharge.

\section{A1 Coefficient of variation of the root mean squared error}

The Coefficient of Variation of the Root Mean Squared Error (CV(RMSE), Eq. A1) is similar to an $R^{2}$ error as it measures the degree of data scatter.

$\mathrm{CV}(\mathrm{RMSE})=\sqrt{\frac{\sum_{i=1}^{N}\left(Q_{\mathrm{ORCH}_{i}}-Q_{\mathrm{obs}_{i}}\right)^{2}}{N}} \times \frac{100}{\overline{Q_{\mathrm{obs}}}}$

where $N$ is the time-step number, $Q_{\mathrm{ORCH}_{i}}$ and $Q_{\mathrm{obs}_{i}}$ $\left(\mathrm{m}^{3} \mathrm{~s}^{-1}\right)$, respectively the simulated and observed streamflows for time-step $i, \overline{Q_{\mathrm{obs}}}\left(\mathrm{m}^{3} \mathrm{~s}^{-1}\right)$ the mean of observed streamflows for the serie.

\section{A2 Nash-Sutcliffe coefficient}

The Nash-Sutcliffe efficiency coefficient (Nash, Eq. A2) assesses the predictive power of hydrological models (Nash and Sutcliffe, 1970). Nash-Sutcliffe efficiencies can range from $-\infty$ to 1 . An efficiency of 1 corresponds to a perfect match of simulated discharge to the observed data. An efficiency of 0 indicates that the model predictions are as accurate as the mean of the observed data, whereas an efficiency less than zero occurs when the observed mean is a better predictor than the model. Essentially, the closer the model efficiency is to 1 , the more accurate the model is.

Nash $=1-\left[\frac{\sum_{i=1}^{N}\left(Q_{\mathrm{ORCH}_{i}}-Q_{\mathrm{obs}_{i}}\right)^{2}}{\sum_{i=1}^{N}\left(\overline{Q_{\mathrm{obs}}}-Q_{\mathrm{obs}_{i}}\right)^{2}}\right]$ 


\section{A3 Coefficient of cross-correlation}

The cross correlation computation is useful to illustrate the time lag existing between two seasonalities. In other words, it deduces the necessary delay $d_{t}$ to get the best correlation between the two seasonalities. The cross-correlation $r$ at delay $d_{t}$ is defined as:

$$
r\left(d_{t}\right)=\frac{\sum^{n}\left[\left(Q_{n}^{\mathrm{ORCH}}-\overline{Q^{\mathrm{ORCH}}}\right) \times\left(Q_{\left(n-d_{t}\right)}^{\mathrm{OBS}}-\overline{Q^{\mathrm{OBS}}}\right)\right]}{\sqrt{\sum^{n}\left(Q_{n}^{\mathrm{ORCH}}-\overline{Q^{\mathrm{ORCH}}}\right)^{2}} \sqrt{\sum^{n}\left(Q_{\left(n-d_{t}\right)}^{\mathrm{OBS}}-\overline{Q^{\mathrm{OBS}}}\right)^{2}}}
$$

where $n$ is the month, $d_{t}$ (months) the delay, $Q^{\mathrm{ORCH}}$ and $\overline{Q^{\mathrm{ORCH}}}\left(\mathrm{m}^{3} \mathrm{~s}^{-1}\right)$, respectively monthly and monthly mean streamflow simulated by the model and $Q^{\text {OBS }}$ and $\overline{Q^{\text {OBS }}}$ $\left(\mathrm{m}^{3} \mathrm{~s}^{-1}\right)$, respectively monthly and monthly mean observed streamflows.

Acknowledgements. We want to acknowledge all our colleagues in the national hydrological services (ANA in Brazil, SENAMHI in Peru and Bolivia and INAMHI in Ecuador) and the French Institute of Research for Development (IRD) who participated to the field campaigns of the HYBAM Program and thus contributed to collecting the data used in this work, which is available on the web page of the ORE-HYBAM (http://www.ore-hybam.org). This work was financially supported by the GIS (Groupement d'Interêt Scientifique) REGYNA (REGioNAlisation des précipitations et impacts hYdrologiques et agronomiques) and the EU-FP7 AMAZALERT (Raising the alert about critical feedbacks between climate and long-term land use change in the Amazon) projects. Correction of NCC forcing in precipitation by ORE HYBAM and simulations with ORCHIDEE were performed using computational facilities of the Institut du Développement et des Ressources en Informatique Scientifique (IDRIS, CNRS, France).

Edited by: W. Buytaert

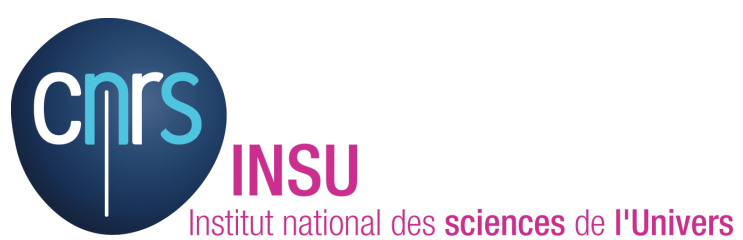

The publication of this article is financed by CNRS-INSU.

\section{References}

Allasia, D., da Silva, B., Collischonn, W., and Tucci, C.: Large basin simulation experience in South America, IAHS Publ., 303, 360-370, 2006.

Araujo, A., Nobre, A., Kruijt, B., Elbers, J., Dallarosa, R., Stefani, P., Von Randow, C., Manzi, A., Culf, A., Gash, J., Valentini, R., and Kabat, P.: Comparative measurements of carbon dioxide fluxes from two nearby towers in a Central Amazonian rainforest: the Manaus LBA site, J. Geophys. Res., 107, 8090, doi:10.1029/2001JD000676, 2002.
Beighley, R., Eggert, K., Dunne, T., He, Y., Gummadi, V., and Verdin, K.: Simulating hydrologic and hydraulic processes throughout the Amazon River basin, Hydrol. Process., 23, 12211235, 2009.

Belward, A., Estes, J., and Kline, K.: The IGBP-DIS global 1-km land-cover data set DISCover: a project overview, Photogramm. Eng. Rem. S., 65, 1013-1020, 1999.

Bonnet, M., Barroux, G., Martinez, J., Seyler, F., MoreiraTurcq, P., Cochonneau, G., Melack, J., Boaventura, G., MauriceBourgoin, L., León, J., Roux, E., Calmant, S., Kosuth, P., Guyot, J. L., and Seyler, P.: Floodplain hydrology in an Amazon floodplain lake (Lago Grande de Curuai), J. Hydrol., 349, 18-30, 2008.

Borma, L., da Rocha, H., Cabral, O., von Randow, C., Collicchio, E., Kurzatkowski, D., Brugger, P., Freitas, H., Tannus, R., Oliveira, L., Reeno, C. D., and Artaxo, P.: Atmosphere and hydrological controls of the evapotranspiration over a floodplain forest in the Bananal Island region, Amazonia, J. Geophys. Res., 114, G01003, doi:10.1029/2007JG000641, 2009.

Callede, J., Guyot, J., Ronchail, J., L Hote, Y., Niel, H., and de Oliveira, E.: Evolution du débit de l'Amazone à Obidos de 1903 à 1999, Hydrolog. Sci. J., 49, 85-98, 2004.

Callede, J., Cochonneau, G., Ronchail, J., Alves, V., Guyot, J., Guimaraes, V., and De Oliveira, E.: Les apports en eau de l'Amazone a l'Ocean Atlantique, Rev. Sci. 1'Eau, 23, 247-273, 2010.

Cochonneau, G., Sondag, F., Guyot, J., Geraldo, B., Filizola, N., Fraizy, P., Laraque, A., Magat, P., Martinez, J., Noriega, L., Ordonez, J., Pombosa, R., Seyler, F., Sidgwick, J., and Vauchel, P.: L'Observatoire de Recherche en Environnement, ORE HYBAM sur les grands fleuves amazoniens, The Environmental Observation and Research project, ORE HYBAM, and the rivers of the Amazon basin, IAHS-AISH Publication, 44-50, 2006.

Coe, M., Costa, M., Botta, A., and Birkett, C.: Long-term simulations of discharge and floods in the Amazon Basin, J. Geophys. Res., 107, 8044, doi:10.1029/2001JD000740, 2002.

Coe, M., Costa, M., and Howard, E.: Simulating the surface waters of the Amazon River basin: impacts of new river geomorphic and flow parameterizations, Hydrol. Process., 22, 2542-2553, 2007.

Coe, M., Costa, M., and Soares-Filho, B.: The influence of historical and potential future deforestation on the stream flow of the Amazon River-Land surface processes and atmospheric feedbacks, J. Hydrol., 369, 165-174, 2009.

Collischonn, W. and Tucci, C.: Large basins hydrologic simulation (in Portuguese), Braz. J. Water Resour., 6, 15-35, 2001.

Collischonn, B., Collischonn, W., and Tucci, C.: Daily hydrological modeling in the Amazon basin using TRMM rainfall estimates, J. Hydrol., 360, 207-216, 2008.

Costa, M. and Foley, J.: Water balance of the Amazon Basin: Dependence on vegetation cover and canopy conductance, J. Geophys. Res., 102, 23973-23989, 1997.

Crétaux, J., Jelinski, W., Calmant, S., Kouraev, A., Vuglinski, V., Nguyen, M., Gennero, M., Nino, F., Rio, R., Cazenave, A., and Maisongrande, P.: SOLS: a lake database to monitor in the Near Real Time water level and storage variations from remote sensing data, Adv. Space Res., 47, 1497-1507, 2011.

d'Orgeval, T.: Impact du changement climatique sur le cycle de l'eau en Afrique de l'Ouest: modélisation et incertitudes, Ph. D. thesis, Universite Paris VI, Paris, France, 2006. 
d'Orgeval, T., Polcher, J., and de Rosnay, P.: Sensitivity of the West African hydrological cycle in ORCHIDEE to infiltration processes, Hydrol. Earth Syst. Sci., 12, 1387-1401, doi:10.5194/hess-12-1387-2008, 2008.

Da Rocha, E.: Balanco de umidade e influencia de condicoes de contorno superficiais sobre a precipitacao da Amazonia, Sao Jose dos Campos, INPE São José dos Campos, 2001, INPOE-10243TDI/904, 210, 2004.

Da Rocha, H., Manzi, O., and Shuttleworth, J.: Evapotranspiration, Geophys. Monogr. Ser., 186, 261-272, 2009.

De Rosnay, P.: Représentation de l'interaction sol-végétationatmosphère dans le modèle de circulation générale du Laboratoire de Météorologie Dynamique thesis, State Univ. Pierre et Marie Curie, Paris VI, 176 pp., 1999.

De Rosnay, P., Bruen, M., and Polcher, J.: Sensitivity of surface fluxes to the number of layers in the soil model used in GCMs, Geophys. Res. Lett., 27, 3329-3332, 2000.

De Rosnay, P., Polcher, J., Bruen, M., and Laval, K.: Impact of a physically based soil water flow and soil-plant interaction representation for modeling large-scale land surface processes, J. Geophys. Res.-Atmos., 107, 4118, doi:10.1029/2001JD000634, 2002.

Decharme, B., Douville, H., Prigent, C., Papa, F., and Aires, F.: A new river flooding scheme for global climate applications: off-line evaluation over South America, J. Geophys. Res., 113, D11110, doi:10.1029/2007JD009376, 2008.

Dingman, S.: Physical Hydrology, Prentice-Hall, Prentice Hall Upper Saddle River, New Jersey, USA, 1994.

Dirmeyer, P., Gao, X., and Oki, T.: GSWP-2: The second Global Soil Wetness Project science and implementation plan, IGPO Publ. Ser., Int. Global Energy and Water Cycle Exp. (GEWEX) Proj. Off., Silver Spring, Md, 65, 2002.

Ducharne, A., Golaz, C., Leblois, E., Laval, K., Polcher, J., Ledoux, E., and de Marsily, G.: Development of a high resolution runoff routing model, calibration and application to assess runoff from the LMD GCM, J. Hydrol., 280, 207-228, 2003.

Ducoudré, N., Laval, K., and Perrier, A.: SECHIBA, a new set of parameterizations of the hydrologic exchanges at the land atmosphere interface within the LMD atmospheric global circulation model, J. Climate, 6, 248-273, 1993.

Espinoza, J., Guyot, J., Ronchail, J., Cochonneau, G., Filizola, N., Fraizy, P., Labat, D., de Oliveira, E., Ordonez, J., and Vauchel, P.: Contrasting regional discharge evolutions in the Amazon basin (1974-2004), J. Hydrol., 375, 297-311, 2009a.

Espinoza, J., Ronchail, J., Guyot, J., Cochonneau, G., Filizola, N., Lavado, W., De Oliveira, E., Pombosa, R., and Vauchel, P.: Spatio-temporal rainfall variability in the Amazon basin countries (Brazil, Peru, Bolivia, Colombia, and Ecuador), Int. J. Climatol., 29, 1574-1594, 2009b.

Fekete, B., Vorosmarty, C., and Grabs, W.: Global, Composite Runoff Fields Based on Observed River Discharge and Simulated Water Balances, Tech. rep., Global Runoff Data Centre, Koblenz, Germany, 1999.

Getirana, A.: Integrating spatial altimetry data into the automatic calibration of hydrological models, J. Hydrol., 387, 244-255, 2010.

Getirana, A., Bonnet, M., Rotunno Filho, O., Collischonn, W., Guyot, J., Seyler, F., and Mansur, W.: Hydrological modelling and water balance of the Negro River basin: evaluation based on in situ and spatial altimetry data, Hydrol. Process., 24, 32193236, doi:10.1002/hyp.7747, 2010.

Getirana, A., Espinoza, J., Ronchail, J., and Rotunno Filho, O.: Assessment of different precipitation datasets and their impacts on the water balance of the Negro River basin, J. Hydrol., 404, 304 322, 2011.

Goovaerts, P.: Geostatistical approaches for incorporating elevation into the spatial interpolation of rainfall, J. Hydrol., 228, 113-129, 2000.

Hagemann, S. and Dumenil, L.: A parametrization of the lateral waterflow for the global scale, Clim. Dynam., 14, 17-31, 1998.

Hamilton, S., Sippel, S., and Melack, J.: Comparison of inundation patterns among major South American floodplains, J. Geophys. Res., 107, 8038, doi:10.1029/2000JD000306, 2002.

Hess, L., Melack, J., Novo, E., Barbosa, C., and Gastil, M.: Dualseason mapping of wetland inundation and vegetation for the Central Amazon basin, Remote Sens. Environ., 87, 404-428, 2003.

Hevesi, J., Istok, J., and Flint, A.: Precipitation estimation in mountainous terrain using multivariate geostatistics, Part I: structural analysis, J. Appl. Meteorol., 31, 661-676, 1992.

Huffman, G., Adler, R., Rudolf, B., Schneider, U., and Keehn, P.: Global precipitation estimates based on a technique for combining satellite-based estimates, rain-gauge analysis, and NWP model precipitation information, J. Climate, 8, 1284-1295, 1995.

Killeen, T., Douglas, M., Consiglio, T., Jørgensen, P., and Mejia, J.: Dry spots and wet spots in the Andean hotspot, J. Biogeogr., 34, 1357-1373, 2007.

Kistler, R., Kalnay, E., Collins, W., Saha, S., White, G., Woollen, J., Chelliah, M., Ebisuzaki, W., Kanamitsu, M., Kousky, V., van den Dool, H., Jenne, R., and Fiorino, M.: The NCEP-NCAR 50year reanalysis: monthly means CD-ROM and documentation, B. Am. Meteorol. Soc., 82, 247-267, 2001.

Legates, D. and Willmott, C.: Monthly average surface air temperature and precipitation. Digital raster data on a 30 min geographic (lat-long) 360720 grid, Global Ecosyst. Datab., Version 1.0 Disc (CD-ROM), edited by: NOAA National Geophysical Data Center, A. Boulder, Colorado, 1992.

Lehner, B. and Döll, P.: Development and validation of a global database of lakes, reservoirs and wetlands, J. Hydrol., 296, 1-22, 2004.

Malhi, Y., Pegoraro, E., Nobre, A., Pereira, M., Grace, J., Culf, A., and Clement, R.: Energy and water dynamics of a Central Amazonian rain forest, J. Geophys. Res., 107, 8061, doi:10.1029/2001JD000623, 2002.

Marengo, J.: Interdecadal variability and trends of rainfall across the Amazon basin, Theor. Appl. Climatol., 78, 79-96, 2004.

Marengo, J.: The characteristics and variability of the atmospheric water balance in the amazon basin: spatial and temporal variability, Clim. Dynam., 24, 11-22, 2005.

Marengo, J.: On the hydrological cycle of the Amazon Basin: a historical review and current state-of-the-art, Rev. Bras. Meteorol., 21, 1-19, 2006.

Martinez, J. and Le Toan, T.: Mapping of flood dynamics and spatial distribution of vegetation in the Amazon floodplain using multitemporal SAR data, Remote Sens. Environ., 108, 209-223, 2007.

Miller, J., Russell, G., and Caliri, G.: Continental-scale river flow in climate models, J. Climate, 7, 914-928, 1994. 
Nash, J. and Sutcliffe, J.: River flow forecasting through conceptual models part I - a discussion of principles, J. Hydrol., 10, 282290, 1970.

New, M., Hulme, M., and Jones, P.: Representing twentieth-century space-time climate variability, Part II: Development of 19011996 monthly grids of terrestrial surface climate, J. Climate, 13, 2217-2238, 2000.

Ngo-Duc, T.: Modélisation des bilans hydrologiques continentaux: variabilité interannuelle et tendances. Comparaison aux observations, Ph. D. thesis, Université Paris VI, Paris, France, 2006.

Ngo-Duc, T., Polcher, J., and Laval, K.: A 53-year forcing data set for land surface models, J, Geophys. Res.-Atmos., 110, D06116, doi:10.1029/2004JD005434, 2005.

Ngo-Duc, T., Laval, K., Ramillien, G., Polcher, J., and Cazenave, A.: Validation of the land water storage simulated by Organising Carbon and Hydrology in Dynamic Ecosystems (ORCHIDEE) with Gravity Recovery and Climate Experiment (GRACE) data, Water Resour. Res., 43, W04427, doi:10.1029/2006WR004941, 2007.

Oki, T., Nishimura, T., and Dirmeyer, P.: Assessment of annual runoff from land surface models using Total Runoff Integrating Pathways (TRIP), J. Meteorol. Soc. Jpn., 77, 235-255, 1999.

Olson, J., Watts, J., and Allison, L.: Carbon in Live Vegetation of Major World Ecosystems (ORNL-5862), Environmental Sciences Division Publication, Oak Ridge National Lab., TN, USA, 1983.

Paiva, R., Collischonn, W., and Tucci, C.: Large scale hydrologic and hydrodynamic modeling using limited data and a GIS based approach, J. Hydrol., 406, 170-181, 2011.

Paz, A., Collischonn, W., Tucci, C., and Padovani, C.: Large-scale modelling of channel flow and floodplain inundation dynamics and its application to the Pantanal (Brazil), Hydrol. Process., 25, 1498-1516, 2010.

Polcher, J.: Les processus de surface à l'échelle globale et leurs interactions avec l'atmosphère, Habilitation à diriger des recherches, Université Paris VI, Paris, France, 2003.

Prigent, C., Papa, F., Aires, F., Rossow, W., and Matthews, E.: Global inundation dynamics inferred from multiple satellite observations, 1993-2000, J. Geophys. Res., 112, 1993-2000, 2007.

Reynolds, C., Jackson, T., and Rawls, W.: Estimating available water content by linking the FAO soil map of the world with global soil profile databases and pedo-transfer functions, in: American Geophysical Union Fall Meeting, EOS Transactions, Vol. 80, Eos. Trans. AGU, 80, Spring Meet. Suppl., S132, 1999.

Ribeiro, A., Collischonn, W., Vieira da Silva, R., and Tucci, C.: Hydrological modelling in Amazonia-use of the MGB-IPH model and alternative data base, in: Predictions in Ungauged Basins: Promise and Progress, edited by: Sivapalan, M., Wagener, T., Uhlenbrook, S., Zehe, E., Lakshmi, V., Lian X., Tachikawa, Y., and Kumar, P., Proc. Foz do lguaçu Symp., 2006, IAHS Publ. 303, IAHS Press, Wallingford, UK, 246-254,2005.

Richey, J., Meade, R., Salati, E., Devol, A., Nordin, C., and Dos Santos, U.: Water discharge and suspended sediment concentrations in the Amazon River: 1982-1984, Water Resour. Res., 22, 756-764, 1986.

Richey, J., Mertes, L., Dunne, T., Victoria, R., Forsberg, B., Tancredi, A., and Oliveira, E.: Sources and routing of the Amazon river flood wave, Global Biogeochem. Cy., 3, 191-204, 1989.
Rudolf, B., Hauschild, H., Rueth, W., and Schneider, U.: Terrestrial precipitation analysis: Operational method and required density of point measurements, Global Precipitations and Climate Change, NATO ASII/26, Springer Verlag, Berlin, 173-186, 1994.

Shuttleworth, W.: Evaporation from Amazonian rainforest, P. Roy. Soc. B-Biol. Sci., 233, 321-346, 1988.

Solomon, S., Qin, D., Manning, M., Chen, Z., Marquis, M., Averyt, K., Tignor, M., and Miller, H.: IPCC, 2007: Climate change 2007: The Physical Science Basis. Contribution of Working Group I to the fourth assessment report of the Intergovernmental Panel on Climate Change, Cambridge University Press, New York, 2007.

Vera, C., Higgins, W., Amador, J., Ambrizzi, T., Garreaud, R., Gochis, D., Gutzler, D., Lettenmaier, D., Marengo, J., Mechoso, C., Nogues-Paegle, J., Silva Dias, P. L., and Zhang, C.: Toward a unified view of the American Monsoon systems, J. Climate, 19, 4977-5000, 2006.

Von Randow, C., Manzi, A., Kruijt, B., De Oliveira, P., Zanchi, F., Silva, R., Hodnett, M., Gash, J., Elbers, J., Waterloo, M., Cardoso, F. L., and Kabat, P.: Comparative measurements and seasonal variations in energy and carbon exchange over forest and pasture in South West Amazonia, Theor. Appl. Climatol., 78, 526, 2004.

Vörösmarty, C., Moore III, B., Grace, A., Gildea, M., Melillo, J., Peterson, B., Rastetter, E., and Steudler, P.: Continental scale models of water balance and fluvial transport: an application to South America, Global Biogeochem. Cy., 3, 241-265, 1989.

Vörösmarty, C., Fekete, B., Meybeck, M., and Lammers, R.: Global system of rivers: Its role in organizing continental land mass and defining land-to-ocean linkages, Global Biogeochem. Cy., 14, 599-621, 2000.

Vose, R., Schmoyer, R., Steurer, P., and Peterson, T.: The Global Historical Climatology Network: long-term monthly temperature, precipitation, sea level pressure, and station pressure data, CDIAC Communications, ORNL/CDIAC-53, NDP-041, Carbon Dioxide Information Analysis Center, Oak Ridge National Laboratory, Oak Ridge, TN, 1992.

Vourlitis, G., Priante-Filho, N., Hayashi, M., Nogueira, J., Caseiro, F., and Campelo Jr., J.: Seasonal variations in the evapotranspiration of a transitional tropical forest of Mato Grosso, Brazil, Water Resour. Res., 38, 30-31, 2002.

WMO: Guide to hydrological practices, WMO-No. 168, World Meteorological Organization, 1994.

Xie, P. and Arkin, P.: Global precipitation: a 17-year monthly analysis based on gauge observations, satellite estimates, and numerical model outputs, B. Am. Meteorol. Soc., 78, 2539-2558, 1997.

Yamazaki, D., Kanae, S., Kim, H., and Oki, T.: A physically based description of floodplain inundation dynamics in a global river routing model, Water Resour. Res., 47, W04501, doi:10.1029/2010WR009726, 2011.

Zhao, M. and Dirmeyer, P.: Production and analysis of GSWP-2 near-surface meteorology data sets, Vol. 159, Center for OceanLand-Atmosphere Studies, 4041 Powder Mill RD., Suite 302, Calverton, MD, 2003. 